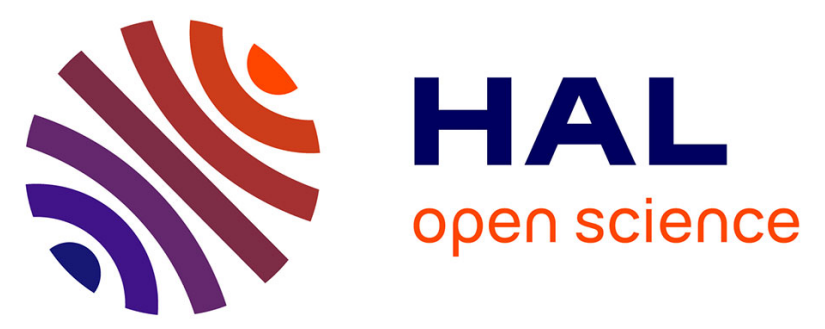

\title{
Study of a large scale powdered activated carbon pilot: Removals of a wide range of emerging and priority micropollutants from wastewater treatment plant effluents
}

R. Mailler, J. Gasperi, Y. Coquet, S. Deshayes, S. Zedek, C. Cren-Olivé, N. Cartiser, V. Eudes, Adèle Bressy, E. Caupos, et al.

\section{To cite this version:}

R. Mailler, J. Gasperi, Y. Coquet, S. Deshayes, S. Zedek, et al.. Study of a large scale powdered activated carbon pilot: Removals of a wide range of emerging and priority micropollutants from wastewater treatment plant effluents. Water Research, 2015, 72, pp.315-330. 10.1016/j.watres.2014.10.047 . hal-01103115

\section{HAL Id: hal-01103115 \\ https://hal-enpc.archives-ouvertes.fr/hal-01103115}

Submitted on 19 Jun 2018

HAL is a multi-disciplinary open access archive for the deposit and dissemination of scientific research documents, whether they are published or not. The documents may come from teaching and research institutions in France or abroad, or from public or private research centers.
L'archive ouverte pluridisciplinaire HAL, est destinée au dépôt et à la diffusion de documents scientifiques de niveau recherche, publiés ou non, émanant des établissements d'enseignement et de recherche français ou étrangers, des laboratoires publics ou privés. 
Study of a large scale powdered activated carbon pilot: removals of a wide range of emerging and priority micropollutants from wastewater treatment plant effluents

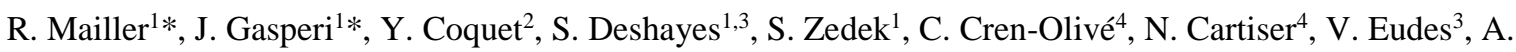
Bressy $^{1}$, E. Caupos ${ }^{1}$, R. Moilleron ${ }^{1}$ G. Chebbo ${ }^{5}$ and V. Rocher ${ }^{6}$

${ }^{1}$ LEESU (UMR MA 102, Université Paris-Est, AgroParisTech), 61 avenue du Général de Gaulle, 94010 Créteil Cedex, France. (E-mail: maillerr@leesu.enpc.fr; gasperi@u-pec.fr)

2 SAUR, Direction de la Recherche et du Développement, 1 rue Antoine Lavoisier, 78064 Guyancourt, France.

${ }^{3}$ LCPP (Laboratoire Central de la Préfecture de Police), 39 bis rue de Dantzig, 75015 Paris, France.

${ }^{4}$ ISA (UMR 5280, Institut des sciences analytiques, CNRS), 5 rue de la Doua, 69100 Villeurbanne, France.

${ }^{5}$ LEESU (UMR MA 102, Université Paris-Est, AgroParisTech), 6-8 avenue Blaise Pascal, Champs-surMarne, 77455 Marne-la-Vallée Cedex 2, France.

${ }^{6}$ SIAAP, Direction du Développement et de la Prospective, 82 avenue Kléber, 92700 Colombes, France.

* Corresponding authors

\section{HIGHLIGHTS}

- $\quad$ Pharmaceuticals and hormones (PhPHs) are well removed (> 60\%) by powdered activated carbon (PAC)

- $\quad 50-95 \%$ removals are also achieved for parabens, bisphenol A and pesticides by PAC

- Treatment degradation leads to substantially lower PhPHs removals by PAC

- The fresh PAC dose is strongly correlated to the process efficacy

- Molecular charge, hydrophobicity and molecular weight have a great influence on the micropollutant fate 


\section{ABSTRACT}

The efficacy of a fluidized powdered activated carbon (PAC) pilot (CarboPlus®) was studied in both nominal (total nitrification + post denitrification) and degraded (partial nitrification + no denitrification) configuration of the Seine Centre WWTP (Colombes, France). In addition to conventional wastewater parameters 54 pharmaceuticals and hormones (PhPHs) and 59 other emerging pollutants were monitored in influents and effluents of the pilot. Thus, the impacts of the WWTP configuration, the process operation and the physico-chemical properties of the studied compounds were assessed in this article.

Among the $26 \mathrm{PhPHs}$ quantified in nominal WWTP configuration influents, 8 have high dissolved concentrations $(>100$ ng/L), 11 have an intermediary concentration (10-100 ng/L) and 7 are quantified below $10 \mathrm{ng} / \mathrm{L}$. Sulfamethoxazole is predominant (about $30 \%$ of the sum of the PhPHs). Overall, $6 \mathrm{PhPHs}$ are poorly to moderately removed $(<60 \%)$, such as ibuprofen, paracetamol or estrone, while 9 are very well removed $(>80 \%)$, i.e. beta blockers, carbamazepine or trimethoprim, and 11 are well eliminated (60-80\%), i.e. diclofenac, naproxen or sulfamethoxazole.

In degraded WWTP configuration, higher levels of organic matter and higher concentrations of most pollutants are observed. Consequently, most PhPHs are substantially less removed in percentages but the removed flux is higher. Thus, the PAC dose required to achieve a given removal percentage is higher in degraded WWTP configuration. For the other micropollutants (34 quantified), artificial sweeteners and phthalates are found at particularly high concentrations in degraded WWTP configuration influents, up to $\mu \mathrm{g} / \mathrm{L}$ range. Only pesticides, bisphenol A and parabens are largely eliminated (50-95\%), while perfluorinated acids, PAHs, triclosan and sweeteners are not or weakly removed $(<50 \%)$. The remaining compounds exhibit a very variable fate from campaign to campaign.

The fresh PAC dose was identified as the most influencing operation parameter and is strongly correlated to performances. Charge and hydrophobicity of compounds have been recognized as crucial for the micropollutant adsorption on PAC, as well as the molecular weight. Finally, a PAC dose of $10 \mathrm{mg} / \mathrm{L}$ allows an average removal of $72-$ $80 \%$ of the sum of the PhPHs in nominal WWTP configuration. The comparaison of the results with those from the scarce other studies tends to indicate that an extrapolation of them to different PAC processes and to other WWTPs could be possible and relevant, taking into account the differences of water quality from WWTP to WWTP.

\section{KEYWORDS}

Pharmaceuticals; emerging pollutants; adsorption; powdered activated carbon; wastewater treatment 
In addition to priority pollutants (EC 2013), many other emerging micropollutants such as pharmaceuticals and hormones (PhPHs), personal care products (PCPs), pesticides, phthalates, artificial sweeteners, etc. are found in the aquatic environment (Jones et al. 2001, Lange et al. 2012, Luo et al. 2014). As bioactive and toxic substances, their environmental effects have been proven (Bolong et al. 2009, Daughton and Ternes 1999). For some of these compounds such as PhPHs and PCPs, wastewater treatment plant (WWTP) discharges have been identified as an important source in the aquatic environment (Halling-Sørensen et al. 1998, Heberer 2002).

Several studies have shown that conventional WWTPs (with primary and biological treatments) substantially remove hydrophobic, volatile and biodegradable micropollutants even if they are not designed and/or optimized for that purpose (Clara et al. 2007, Mailler et al. 2013, Ruel et al. 2012). However, hydrophilic or refractory organic compounds are still present in the treated wastewater at $\mathrm{ng} / \mathrm{L}$ to $\mu \mathrm{g} / \mathrm{L}$ level (Loos et al. 2013). Besides, emerging micropollutants, particularly pharmaceuticals such as diclofenac, may be included in future modifications of existing European (EC 2013) or national regulations. Among the solutions to reduce the emerging contaminant discharges into the environment, the implementation of a tertiary treatment in conventional WWTPs is more and more considered by WWTP managers and decision makers. These technologies, such as membrane filtration, advanced oxidation and adsorption processes, are principally adapted from drinking water industry. They have been employed for a long time, but the generalization of their applications to wastewater treatment has been seriously considered recently. However, very few studies have shown the potential of such technologies to remove organic pollutants from treated wastewater (Boehler et al. 2012, Margot et al. 2013) and their economic feasibility (Abegglen and Siegrist 2012).

In this context, a large scale powdered activated carbon (PAC) pilot has been set up at the Seine Centre WWTP, treating wastewater from Paris conurbation and supervised by the Parisian public sanitation service (SIAAP). An extended sampling strategy, both in number of campaigns $(\mathrm{n}=14)$ and compounds $(\mathrm{N}=113)$, has been built.

Thus, this paper aims at displaying and comparing the performances of such a process for micropollutant removal in both nominal and degraded WWTP configurations, and to assess the influence of both operation parameters and physico-chemical properties of the pollutants. First, the influent dissolved concentrations for both micropollutants and 
conventional wastewater parameters are discussed and compared to the literature. Then, the removals of the molecules are examined, as well as the effluent dissolved concentrations and the water quality. The difference between a normal and a degraded configuration of the WWTP is particularly analyzed. Finally, the influence of operation parameters (fresh PAC dose, total mass of carbon in the reactor, hydraulic velocity) and physico-chemical properties of the compounds (charge, hydrophobicity, size, functional groups, etc.) are also examined. Such results are of high interest and very relevant considering the poverty of the literature regarding the removal of micropollutants from wastewater by PAC.

\section{MATERIALS AND METHODS}

1. Site and process description

In nominal configuration, the Seine Centre WWTP treats $240000 \mathrm{~m}^{3}$ per day of domestic wastewater from Paris city, corresponding to 900000 population equivalents. In these conditions (total nitrification + post denitrification), the treatment process is composed by three major steps: pre, primary and biological treatments. After the pretreatment (screening, grit and oil removal units), a physicochemical lamellar settling unit (Densadeg ${ }^{\circledR}$ ) removes a great part of the particulate and colloidal pollution thanks to coagulant (ferric chloride) and flocculant (anionic polymer) addition. Finally, a three stage biofiltration system achieves the biological treatment. In nominal configuration, the first stage (Biofor ${ }^{\circledR}$ filters - biolite medium), allows the treatment of carbonaceous pollution in aerobic conditions, and the second (Biostyr ${ }^{\circledR}$ filters - biostyrene medium) and third (Biofor ${ }^{\circledR}$ filters) stages remove the nitrogenous pollution respectively in aerobic (total nitrification) and anoxic (denitrification) conditions (Rocher et al. 2012). This WWTP is able to switch to a degraded configuration to treat $405000 \mathrm{~m}^{3}$ of water per day but a partial nitrification and no denitrification are performed. A detailed layout of the WWTP in both configurations is given in supporting material - Figure S1.

The tertiary treatment process studied (CarboPlus ${ }^{\circledR}$ - Figure 1) is fed by Seine Centre treated effluents and treats between 700 and $1200 \mathrm{~m}^{3} /$ day. This pilot consists in a $5 \mathrm{~m}$ high reactor with a surface area of $4 \mathrm{~m}^{2}$, where water flows upstream through a fluidized bed of PAC. Depending on the mass of PAC inside the reactor and the hydraulic velocity, the bed depth varies between 1 and $3 \mathrm{~m}$. A dose of fresh PAC is continuously injected. At steady state, a comparable amount of PAC is regularly removed from the reactor to obtain a solid retention time (SRT) of 5 to 7 days, and an 
overall concentration of 5 to $10 \mathrm{~g} / \mathrm{L}$ of PAC is maintained inside the bed. In addition, coagulant (ferric chloride) and flocculant (anionic polymer) are injected continuously with the fresh PAC to stabilize the bed expansion and to prevent the leakage of PAC with treated water. The hydraulic velocity can technically vary from 6 to $12 \mathrm{~m} / \mathrm{h}$ and the hydraulic retention time considering the reactor size is comprised between 25 and $50 \mathrm{~min}$. The observed contact time between the PAC bed and the water varies between 10 and 20 min considering the bed depth and the hydraulic velocity.

FIGURE 1

2. Study and sampling strategy

The study has been initially built to assess the process efficacy in different operation configuration (Table 1) during 14 campaigns (from July to December 2013). However, the Seine Centre WWTP operated in degraded configuration during the 5 lasts campaigns (unplanned), because it received additional water from another WWTP that was in maintenance. Taking this into account, the campaigns performed have been organized in two phases in the results and discussion sections of the article. The first 9 campaigns, corresponding to phase 1, were performed during nominal WWTP configuration. The last 5 campaigns were carried out under degraded WWTP configuration, corresponding to phase 2 .

In addition, different process configurations were tested during the first phase (Table 1) by varying the fresh PAC dose in the ranges operationally feasible within the process. Thus, three moderate PAC doses (5-10-20 mg/L) and one high PAC dose $(70 \mathrm{mg} / \mathrm{L})$, as well as four hydraulic velocities $(6-7-8-10 \mathrm{~m} / \mathrm{h})$ were tested, allowing determining their influences on performances. The $70 \mathrm{mg} / \mathrm{L}$ of PAC campaign was performed to determine whether some compounds could still be recalcitrant to adsorption at high dose. Information about operation parameters during this phase are given in Table 1. In contrary, a stable and intermediate configuration $(10 \mathrm{mg} / \mathrm{L}$ of PAC and $7 \mathrm{~m} / \mathrm{h})$, considered as the recommended configuration of the process, was maintained during the second phase.

Thus, this experimental design allows assessing the influences of both the process operation parameters and the configuration of the WWTP.

TABLE 1

The same sampling procedure was applied for the 14 campaigns. Analyzes were performed on the dissolved phase. 24-h composite samples of $20 \mathrm{~L}$ were collected using automatic refrigerated samplers $\left(4^{\circ} \mathrm{C}\right)$ equipped with glass bottles, properly cleaned, and Teflon ${ }^{\circledR}$ pipes to avoid any contamination or loss. When sampling was completed, glass bottles were collected, very carefully homogenized and sub-samples were distributed for analyses. Each sample was filtered 
using $0.7 \mu \mathrm{m} \mathrm{GF/F}$ filters $\left(\right.$ Whatman $^{\circledR}$ ). All samples were analyzed within 48 -h after sampling, due to transport time to the laboratories involved, except for sweeteners. As recommended by the laboratory performing the artificial sweeteners analyses (internal tests), these samples were acidified $(1 \%$ volumetric $\mathrm{HCl})$ and stored in fridge $\left(4^{\circ} \mathrm{C}\right)$ until analyses.

\section{Activated carbon characterization}

Activated carbon characteristics are very important in the adsorption mechanisms and can strongly influence the micropollutant fate (Çeçen and Aktas 2012). Apart from BET (Brunauer, Emmett and Teller) specific surface and particle size, the mesoporous structure is the best suited for micropollutants adsorption (Çeçen and Aktas 2012, Ebie et al. 2001), as it reduces the impact of organic matter competition with micropollutants. Thus, a mesoporous PAC (DaCarb PB-170) was tested in the pilot, after preliminary lab tests comparing different PACs. The characteristics of this PAC are given in supporting material - Table 1. Globally, the selected PAC is featured by a high BET surface of $957 \pm 28 \mathrm{~g} / \mathrm{m}^{2}$, which is close to BET specific surfaces found in the literature, often comprised between 700 and 1500 $\mathrm{m}^{2} / \mathrm{g}$ (Çeçen and Aktas 2012, de Ridder et al. 2013, Margot et al. 2013). In addition, its granulometry is large but its median particle diameter is rather low $(<20 \mu \mathrm{m})$, which theoretically enhance the adsorption kinetics. PAC observations by scanning electron microscopy are provided in supporting material - Figure S2.

\section{Pollutants and analytical procedures}

In all samples, conventional wastewater parameters were analyzed by SIAAP French accredited laboratory (COFRAC, supporting material - Table S2) to characterize the general quality of water. These parameters include: dissolved organic carbon (DOC), chemical oxygen demand (COD), biological oxygen demand $\left(\mathrm{BOD}_{5}\right)$, UV absorption at $254 \mathrm{~nm}$ (UV254), total Kjeldahl nitrogen (TKN), $\mathrm{NH}_{4}{ }^{+}, \mathrm{NO}_{3}{ }^{-}, \mathrm{NO}_{2}{ }^{-}, \mathrm{PO}_{4}{ }^{3-}$, total phosphorous (TP) and total suspended solids (TSS). All analyses were performed according to standards (supporting material - Table S2).

113 micropollutants were monitored in the dissolved phase (Table 2). First, pharmaceuticals ( $N=44, N$ for the number of compounds) and hormones ( $\mathrm{N}=10)$ were analyzed for all campaigns, as they are the compounds targeted by the process. In addition to these molecules, complementary analyses were performed for other micropollutants $(\mathrm{N}=59)$ during phase 2. Thus, chlorinated solvents $(\mathrm{N}=3)$, perfluorinated acids $(\mathrm{N}=2)$, pesticides $(\mathrm{N}=23)$, bisphenol $A$, 
alkylphenols $(\mathrm{N}=2)$ and phthalates $(\mathrm{N}=4)$ were analyzed in all campaigns of phase 2, while PAHs $(\mathrm{N}=13$ - the 16 USEPA PAHs excluding naphthalene, acenaphthene and acenaphthylene) and PCPs (N=7) were monitored in 3 campaigns and artificial sweeteners $(\mathrm{N}=4)$ in 4 campaigns. The full list of molecules is given in supporting material - Table S3, as well as their respective limits of quantification (LQ).

Micropollutant analyses were performed by 4 laboratories: the Institute of Analytical Sciences (ISA - Villeurbanne, France) from CNRS, in charge of the PhPHs, chlorinated solvents, perfluorinated acids, pesticides and bisphenol A, the Water Environment and Urban Systems laboratory (LEESU - Créteil, France), in charge of PAHs and PCPs, the Central laboratory of the Police Prefecture (LCPP - Paris, France), in charge of phthalates and alkylphenols, and the Water Technology Center (TZW - Karlsruhe, Germany), in charge of artificial sweeteners.

\section{TABLE 2}

Information about the analytical procedures (Table 2) are available in the literature for PhPHs (Vulliet et al. 2011), pesticides and chlorinated solvents (Barrek et al. 2009), PAHs (Bressy et al. 2012), alkylphenols and phthalates (Bergé et al. 2014), sweeteners (Scheurer et al. 2009), and for PCPs (Gasperi et al. 2014).

\section{Data processing}

The statistical calculations were performed separately for the nominal $(n=9)$ and the degraded ( $=5)$ WWTP configurations, for comparison purposes. When the number of values available was higher than six, box plots were plotted with minimum, $1^{\text {st }}$ quartile $(\mathrm{Q} 1), 3^{\text {rd }}$ quartile $(\mathrm{Q} 3)$ and maximum values of the series. In contrary $(\leq 6$ values), individual values were plotted. Finally, the results given in text, concentrations as well as removals, are average results \pm standard deviations ( $>6$ values) or minimum - maximum values ( $\leq 6$ values).

As no direct assessment of the uncertainties was performed, and to have an idea of the robustness of the data, limit values of 5 times the LQ were defined for each compound. The uncertainty was assumed moderate for concentrations measured above these limit values $(<30 \%)$, while the uncertainty was considered high for concentrations below them (>30\%). Such an approach has already been adopted by (Ruel et al. 2011), which stated that the uncertainty on the micropollutant concentration in wastewater is generally comprised between 30 and $100 \%$ when the value measured is lower than 2.5 to 10 times the LQ, depending on the compound, and lower than $30 \%$ when higher than this value. Considering that, the removal of micropollutants was estimated only in several situations to limit the propagation of 
uncertainties and provide more reliable results. When the compound was quantified above 5 times the LQ in influents and above the LQ in effluents, the removal was conventionally calculated. In addition, when the compound was quantified above the LQ in influents (>LQ or $>5 \mathrm{x}$ LQ) and below the LQ in effluents, the removal was estimated using LQ/2 instead of the effluent concentration. The removals were not calculated when concentrations of both influents and effluents were measured between the LQ and 5 times the LQ.

Finally, 4 classes of behaviors were defined regarding the obtained removals: very good (>80\%), good (60-80\%), moderate $(30-60 \%)$ and poor $(<30 \%)$.

\section{RESULTS AND DISCUSSION}

1. Quality of influents in nominal and degraded WWTP configuration

\subsection{Conventional wastewater parameters in influents}

As displayed in Table 3, the pilot influents are characterized by relatively low values of the conventional wastewater parameters in nominal WWTP configuration, particularly DOC $(5.6 \pm 0.9 \mathrm{mgC} / \mathrm{L}), \mathrm{UV}-254\left(0.110 \pm 0.013 \mathrm{~cm}^{-1}\right), \mathrm{COD}$ and $\mathrm{BOD}_{5}\left(26 \pm 11\right.$ and $\left.4.8 \pm 3.5 \mathrm{mgO}_{2} / \mathrm{L}\right)$, TKN $(1.5 \pm 0.2 \mathrm{mgN} / \mathrm{L}), \mathrm{NH}_{4}{ }^{+}(<0.3 \mathrm{mgN} / \mathrm{L}), \mathrm{TSS}(3 \pm 1 \mathrm{mg} / \mathrm{L}) \mathrm{and} \mathrm{TP}$ ( $<0.3 \mathrm{mgP} / \mathrm{L})$. Indeed, this WWTP achieves very high removals of TSS (98\%), COD (92\%), TN (76\%) and TP (95\%) in nominal configuration (Mailler et al. 2013). In addition, a substantial fraction of the DOC $(\approx 20 \%)$ is due to residual methanol from the post denitrification step (SIAAP source), in contrary to DOC from the degraded WWTP configuration (no denitrification).

In this study, the WWTP effluents are rather less concentrated (DOC, UV-254, etc.) than effluents from other studies focusing on PAC adsorption from wastewater. Besides, effluents with average DOC values of $9.6-14.4 \mathrm{mgC} / \mathrm{L}$ and UV-254 of $0.239-0.397 \mathrm{~cm}^{-1}$ were recently studied by (Altmann et al. 2014), while DOC concentration of the water studied by (Löwenberg et al. 2014) was $8.8 \pm 1.2 \mathrm{mg} / \mathrm{L}$. Similarly, (Margot et al. 2013) performed PAC adsorption on biological treatment effluents with DOC of $7.3 \pm 1.9 \mathrm{mgC} / \mathrm{L}$. Only the study of (Boehler et al. 2012) provides micropollutant removal by PAC data with lower DOC concentration water, between 5.6 and $8.9 \mathrm{mgC} / \mathrm{L}$. 
The degraded configuration, with partial nitrification and no denitrification, induces a notable increase of concentrations, particularly DOC $(7.5 \pm 0.5 \mathrm{mgC} / \mathrm{L})$ and the UV-254 $\left(0.139 \pm 0.011 \mathrm{~cm}^{-1}\right)$. In addition, as no denitrification is performed in this WWTP configuration, the composition of the DOC is different without residue of methanol. The difference of DOC concentration is then even higher between the two WWTP configurations.

The concentration of $\mathrm{NH}_{4}{ }^{+}$in influents highlights the degradation of the nitrification step, with concentrations up to 4.4 $\pm 0.7 \mathrm{mgN} / \mathrm{L}$. Similarly, the highest concentration of $\mathrm{NO}_{3}{ }^{-}$in influents from degraded configuration $(23.7 \pm 2.1 \mathrm{mgN} / \mathrm{L})$ reflects the lack of denitrification. Finally, the TSS concentration is doubled when WWTP configuration is degraded (Table 3). Overall, the obtained quality of influents in this WWTP configuration is degraded and quite comparable to the one from (Margot et al. 2013).

The higher quantity of organic matter and most of pollutants in degraded WWTP configuration should be unfavorable to micropollutant adsorption. Indeed, it has been demonstrated that a higher DOC concentration induces a stronger competition effect (Delgado et al. 2012, Margot et al. 2013).

\subsection{Micropollutant concentrations in influents from nominal WWTP configuration}

Among the $54 \mathrm{PhPHs}$ monitored, a total of 26 compounds were quantified at least during the nominal WWTP configuration. During this WWTP configuration, 14 were systematically quantified in influents, 12 in several samples but 28 were never quantified (supporting material - Table S4). The dissolved concentrations of the 26 compounds, in both nominal and degraded configuration of the WWTP, are presented in Table 2, with their occurrences.

8 compounds were measured in influents at average dissolved concentrations higher than $100 \mathrm{ng} / \mathrm{L}$ : sulfamethoxazole $(993 \pm 817 \mathrm{ng} / \mathrm{L})$, ofloxacin $(412 \pm 315 \mathrm{ng} / \mathrm{L})$, carbamazepine $(215 \pm 85 \mathrm{ng} / \mathrm{L})$, atenolol $(185 \pm 51 \mathrm{ng} / \mathrm{L}), \mathrm{diclofenac}$ $(184 \pm 91 \mathrm{ng} / \mathrm{L})$, oxazepam $(139 \pm 128 \mathrm{ng} / \mathrm{L})$ and erythromycin $(124 \pm 32 \mathrm{ng} / \mathrm{L}) .7$ compounds were measured at concentrations lower than $10 \mathrm{ng} / \mathrm{L}$, especially estrone $(9 \pm 3 \mathrm{ng} / \mathrm{L})$ and ibuprofen $(9 \pm 5 \mathrm{ng} / \mathrm{L})$. The 11 remaining compounds have average concentrations between 10 and $100 \mathrm{ng} / \mathrm{L}$, i.e. naproxen $(33 \pm 28 \mathrm{ng} / \mathrm{L})$, trimethoprim $(64 \pm 79$ $\mathrm{ng} / \mathrm{L})$ or propranolol $(97 \pm 27 \mathrm{ng} / \mathrm{L})$.

These concentrations are rather in accordance with data available in the literature for WWTP effluents (Deblonde et al. 2011, Loos et al. 2013, Luo et al. 2014, Miège et al. 2009), although they are overall in the lower part of the range (i.e. analgesics). This could be due to i) the dilution of the Parisian wastewater (combined sewer) by parasite waters (Gasperi 
et al. 2008) and ii) intense biological treatment including a total nitrification step, known to enhance the biodegradation of micropollutants (Clara et al. 2005, McAdam et al. 2010). Sulfamethoxazole contributes about $30 \%$ of the total PhPHs concentration, and its concentration lies in the upper part of the range found in the literature. No data were found for testosterone, sulfadimerazine, sulfameter, and very scarce information are available for sulfadiazine, sulfathiazole, fenofibrate and lorazepam. A short review as regard concentrations found in WWTP effluents for these compounds (23 references) is given in supporting material - Table S5.

In addition, most compounds are measured above 5 times their LQ (Table 3), leading to a moderate uncertainty on the concentration. Sulfadimerazine, sulfadiazine, sulfameter, sulfathiazole, fenofibrate and testosterone are rather measured between LQ and 5 times LQ, corresponding to high uncertainties, and the corresponding removals were consequently not calculated.

\subsection{Micropollutant concentrations in influents from degraded WWTP configuration}

In the degraded configuration, $21 \mathrm{PhPHs}$ were quantified. A similar pattern is observed but most of the PhPHs are measured at higher average dissolved concentrations than in nominal WWTP configuration (Table 2), particularly paracetamol (x200 based on average concentrations), ibuprofen (x100), ketoprofen (x10) and bezafibrate (x10). This is mainly explained by both seasonal variations (phase 1 June-October, phase 2 November-December) and the lack of nitrification since this step has been identified as crucial for micropollutant biodegradation in biological treatments, especially for easily biodegradable molecules by biological treatments (Joss et al. 2005, Margot et al. 2013, Radjenović et al. 2009). The degree of nitrification is then correlated to some PhPHs biodegradation (Margot et al. 2013), and a total nitrification, as in nominal WWTP configuration, is known to be more efficient than a partial nitrification (Joss et al. 2008), as in degraded WWTP configuration. This results in lower concentrations in discharges from nominal WWTP configuration. Finally, the total concentration of the PhPHs doubles from $2729 \pm 1057$ ng/L in nominal WWTP configuration to $4956 \pm 3628 \mathrm{ng} / \mathrm{L}$ in degraded WWTP configuration, mainly due to the increase of paracetamol and ibuprofen concentrations. In contrary, four compounds are measured at notably lower concentrations: sulfamethoxazole, carbamazepine, ofloxacin and ciprofloxacin, probably because of seasonal variability.

A total of 59 other emerging micropollutants were also monitored during phase 2 in order to improve and enlarge the performance overview of the PAC treatment. Concentrations are presented in Table 3. Among them, monitored during 
degraded WWTP configuration, 34 were measured above the LQ. Only 3 pesticides (atrazine, diuron and isoproturon) out the 23 pesticides investigated were quantified due to both a low occurrence in treated wastewater and high LQ. Most of the compounds were always found in influents, especially PFOS, PFOA, bisphenol A, nonylphenols (NP), para-tert-octylphenol (t-OP), bis(2-ethylhexyl) phthalate (DEHP), artificial sweeteners, triclosan and parabens.

A wide variety of dissolved concentrations is observed, from a few ng/L to more than $1000 \mathrm{ng} / \mathrm{L}$. Phthalate levels are rather high, ranging from 300 to $3000 \mathrm{ng} / \mathrm{L}$. Similarly, acesulfame and sucralose exhibit the highest concentrations by far, respectively $8725 \pm 602$ and $7150 \pm 745 \mathrm{ng} / \mathrm{L}$, due to very poor removals by conventional WWTPs (Lange et al. 2012). Artificial sweeteners have been recently recognized as a new class of emerging environmental contaminants (Lange et al. 2012), highly persistent, and their toxicity in the environment is still not well known. Bisphenol A, NP, cyclamate and saccharin are found at lower concentrations (100-1 $000 \mathrm{ng} / \mathrm{L})$, as well as diuron, isoproturon, PFOS, PFOA and parabens (10-100 ng/L). Then, all the PAHs present dissolved concentrations lower than $20 \mathrm{ng} / \mathrm{L}$ in the effluents. Finally, as the concentrations presented for these micropollutants were acquired in degraded WWTP configuration, it can be assumed that they should be lower or equal in nominal WWTP configuration. Levels found are very similar to other studies for pesticides, perfluorinated acids, bisphenol A, triclosan and phthalates (Bergé et al. 2013, Deblonde et al. 2011, Loos et al. 2013, Luo et al. 2014, Zareitalabad et al. 2013). In contrary, substantially higher levels of sweeteners (Berset and Ochsenbein 2012, Ordóñez et al. 2012) and PAHs (Fatone et al. 2011, Qiao et al. 2014, Sánchez-Avila et al. 2011) were found in WWTP effluents in the literature. Similarly, levels of parabens found are rather high compared to the literature (Chen et al. 2012, Yu et al. 2012b). In particular, concentrations are slightly higher than those reported by (Geara-Matta 2012) for the same WWTP discharges, highlighting the impact of the degraded configuration. More information about data available in the literature is given in supporting material - Table S5.

Like PhPHs, most of these other emerging micropollutants feature concentrations higher than 5 times their LQ, except three PAHs (anthracene, benzo[a]anthracene and dibenzo[ah]anthracene) and some campaigns for NP, benzylbutyl phthalate (BBP), cyclamate and two parabens (benzyl and butyl paraben).

2. Efficacy of PAC in nominal and degraded WWTP configurations

\subsection{Conventional wastewater parameter removal in nominal and degraded WWTP configurations}


An overall improvement of the water quality is observed after the PAC treatment. In nominal WWTP configuration, concentration removals of DOC $(35 \pm 24 \%), \mathrm{UV}-254(32 \pm 14 \%)$, COD $(13 \pm 14 \%)$ and $\mathrm{BOD}_{5}(39 \pm 19 \%)$ are observed ( $\mathrm{n}=9$, average PAC dose of $14 \mathrm{mg} / \mathrm{L})$. These results are rather similar or lower than those of (Margot et al. 2013), despite the same average PAC dose. Actually, this difference could be due to the filtration unit after the PAC contact tank in their study, which was recognized as the main cause of the general water quality improvements because it was biologically active. Furthermore, they evaluated between 20 and $35 \%$ the DOC removal due to the PAC against $35 \pm 24 \%$ and $23 \pm 4 \%$ in nominal and degraded configurations respectively. Similarly, (Boehler et al. 2012) observed a DOC removal between 15 and $48 \%$, consistent with previously cited results.

In degraded WWTP configuration, the influent quality (Table 3) is degraded (Figure 4). Indeed, DOC is rather better removed both in percentage and concentration in nominal WWTP configuration, despite higher influent concentrations. In contrary, UV-254, COD, $\mathrm{BOD}_{5}$ and $\mathrm{TKN}$ are similarly removed in both WWTP configurations. In addition, the presence of $\mathrm{NH}_{4}{ }^{+}$in degraded WWTP effluents (Table 3) allows highlighting that a nitrification process occurs in the

\subsection{Micropollutant removal in nominal WWTP configuration} pilot, with a removal of about $20 \pm 7 \%$. This confirms the findings of (Margot et al. 2013) even if authors quote a higher $\mathrm{NH}_{4}{ }^{+}$removal $(85 \pm 20 \%)$ because of the biologically active filtration unit after the PAC contact tank. The formation of $\mathrm{NO}_{3}{ }^{-}$and $\mathrm{NO}_{2}{ }^{-}$confirms the nitrification process.

The overall performances of the pilot in both nominal and degraded WWTP configuration are presented in Figure 2. For each compound, the results from nominal configuration are given on the left hand and the results from degraded configuration on the right hand. A short literature review about the micropollutant removals by PAC is also provided in supporting material - Table S5.

In nominal WWTP configuration with a fresh PAC dose at $10 \mathrm{mg} / \mathrm{L}(\mathrm{n}=3)$, paracetamol and ibuprofen are poorly removed, and 4 compounds are moderately removed by the pilot, including estrone (32-61\%, min-max). In contrary, 9 substances are very well removed, including propranolol (96-98\%), atenolol (86-92\%), trimethoprim (84-98\%), carbamazepine (86-97\%), oxazepam (82-91\%), bezafibrate $(75-99 \%)$ and ciprofloxacin (76-91\%). Finally, the 11 
remaining compounds are well removed, i.e. ofloxacin (63-89\%), naproxen (46-99\%), sulfamethoxazole (53-72\%) and diclofenac $(72-85 \%)$.

To the best of our knowledge, papers dealing with the removal of micropollutants from wastewater by PAC are very scarce, especially at large scale. Among the $26 \mathrm{PhPHs}$ quantified, only 16 have been already studied in a comparable context - adsorption from treated wastewater by PAC. Despite rather large standard deviations in our study, removals are similar to those of these studies (Altmann et al. 2014, Boehler et al. 2012, Löwenberg et al. 2014, Margot et al. 2013) for these 16 common PhPHs, as shown by supporting materials - Table S3 and Figure S3. Only ibuprofen and estrone removals are notably lower in our study, probably because of their lower influent concentrations. In contrary, ciprofloxacin is better removed than in the literature. As the average fresh PAC doses are comparable for these studies (14-15 mg/L), this suggests that micropollutant adsorption on PAC is likely to be a very stable phenomenon and that these results could be extrapolated to other PAC treatments. A generalization of these results to other WWTPs and PAC processes could be then possible and relevant, even if efficacy in waters with slightly higher DOC concentrations should be slightly lower. In addition, some papers have already observed comparable performances over PhPHs with advanced oxidation processes such as ozonation (Altmann et al. 2014, Margot et al. 2013). For several compounds, scarce data are available displaying their removal by grain activated carbon filter and/or PAC batch experiments with surface water (paracetamol, roxithromycin, erythromycin and testosterone), while no reference was found for sulfadimerazine, sulfameter, sulfadiazine, sulfathiazole, lorazepam and fenofibrate (supporting material - Table S5). Overall, observed removals are similar to those from former studies (Altmann et al. 2014, Boehler et al. 2012, Löwenberg et al. 2014, Margot et al. 2013, Ruel et al. 2012, Snyder et al. 2007, Westerhoff et al. 2005).

The removals vary due to variations of the fresh PAC doses (supporting material - Table S1) and of the influent concentrations. Despite this, the variations of removal percentages are relatively moderate for most of the compounds, around 5-15\% between Q1 and Q3, except for paracetamol, sulfamethoxazole and bezafibrate, which have higher variations of 20-30\%. Moreover, the observed variations are lower for well and very well removed compounds (i.e. beta blockers or trimethoprim), i.e. below $10 \%$.

\subsection{Micropollutant removal in degraded WWTP configuration}


In degraded WWTP configuration, different impacts can be observed on PhPHs removal percentages, depending on the compound (Figure 4). First, paracetamol and ibuprofen are better removed in percentage in degraded configuration, most likely due to their higher influent concentrations. Several compounds are rather similarly removed in both configurations, i.e. both beta blockers, trimethoprim, sulfadiazine and ofloxacin, despite variations of influent concentrations. Then, lower removals in percentage are observed for a majority of compounds, during degraded WWTP configuration (Figure 4), despite higher influent concentrations. Nevertheless, the removed pollutant load is higher in degraded than in nominal WWTP configuration (ketoprofen, naproxen, diclofenac, trimethoprim, roxithromycin, metronidazole, atenolol, propranolol, oxazepam, lorazepam, bezafibrate and estrone). In contrary, carbamazepine, ciprofloxacin and sulfamethoxazole have lower removal in degraded configuration due to lower influent concentrations. This decrease of the micropollutant removals can be explained by both the variations of influent concentrations and the water quality change. As demonstrated by higher DOC and UV-254, the influents in degraded WWTP exhibit higher organic matter levels, inducing a stronger competition with micropollutants for adsorption on the PAC by direct site competition and pore blocking (de Ridder et al. 2011, Delgado et al. 2012). In particular, the negative relation between DOC concentration and micropollutant removals has already been highlighted in the literature (Altmann et al. 2014, Margot et al. 2013).

Finally, the sum of PhPHs is similarly removed in nominal and degraded WWTP configurations (72-80\% vs $70-81 \%)$. This is mainly explained by higher removals of the high concentrated pollutants such as paracetamol and ibuprofen and slightly lower removals of the other compounds.

Regarding the other emerging micropollutants monitored (Figure 3), atrazine (51-64\%, min-max), isoproturon (51-83\%) and to a greater extent diuron (82-96\%) have a good affinity for PAC, confirming the suitability of the process for pesticide removal. This confirms other studies observations (Margot et al. 2013, Ruel et al. 2012, Snyder et al. 2007), even if atrazine is slightly less removed in our case (lower PAC dose). In addition, parabens (>70\%), particularly ethyl paraben (88-94\%) and propyl paraben (91-96\%), are also well or very well removed. As far as authors know, this is the first study displaying their fates within PAC in wastewater, as well as for phthalates and PAHs. In contrary, acesulfame (9-19\%), sucralose (6-26\%), triclosan (18-29\%) and PFOS (6-52\%) are poorly removed by adsorption. For PFOA, no clear conclusion can be drawn, since a systematic negative removal was observed, with concentrations always higher in effluents than in influents. No sampling blanks were performed for the study, but this potential contamination may result from Teflon ${ }^{\circledR}$ pipes or elements of the automatic samplers. 
The 9 remaining compounds have variable removals but are rather moderately removed, such as saccharin (33-54\%), DEHP (49-63\%), bisphenol A (49-78\%) or NP (3-97\%). The removal of these substances from wastewater by adsorption was poorly studied, but (Ruel et al. 2012) reported that within a granulated activated carbon treatment, DEHP and NP are respectively moderately $(30-70 \%)$ and poorly $(<30 \%)$ removed. (Yu et al. 2008) also observed poor removal for NP by activated carbon. Similarly, (Scheurer et al. 2010) observed that moderate to good removals can be achieved by PAC adsorption for saccharin and sucralose, what is consistent with results obtained in our study. Finally, bisphenol A was found to be slightly better removed from wastewater by PAC in (Margot et al. 2013). Regarding PAHs, the variation of removal is high but these compounds are overall not eliminated by the process or poorly removed (10-40\% for pyrene, fluoranthene, indeno[123]pyrene and benzo[ghi]perylene).

Even if the number of samples for these substances is limited, the variations of pesticide, sweetener and paraben removals from campaign to campaign are lower than $30 \%$. Contrariwise, phthalates (except DEHP), PAHs, alkylphenols and perfluorinated acids have large variations of removals.

\subsection{Water quality after the PAC treatment}

The tertiary PAC treatment doesn't radically change the micropollutant pattern between influent and effluent (Table 3), but it substantially decreases their dissolved concentrations. As the generalization of tertiary treatments to all WWTPs would depend strongly on regulations, having an idea of the levels that could be required for these compounds is crucial. Instead of an overall removal (average removal of $80 \%$ ), such as required in Switzerland, environmental quality criteria (EQC) for freshwaters, comparable to environmental quality standards (EQS) for priority pollutants from (EC 2013), could be used as references. Such EQC have been proposed in Switzerland by the Ecotoxicity Centre of EAWAG (supporting material - Table S6) (Götz et al. 2010, Kase et al. 2011). A comparison of the concentrations measured in effluents from the PAC treatment with these EQC or EQS enables to state if this process efficacy is sufficient to reach references. However, these EQC/EQS apply for freshwaters and not effluents from WWTP, so a dilution factor should be considered when evaluating the quality of the treatment and the compliance with regulations.

For PhPHs, naproxen, trimethoprim and atenolol concentrations are already measured below these proposed values before treatment. Ibuprofen, sulfamethoxazole, ciprofloxacin, propranolol, carbamazepine and bezafibrate are always 
measured below levels proposed after the treatment, while a fresh PAC dose of $20 \mathrm{mg} / \mathrm{L}$ allows decreasing diclofenac, erythromycin and estrone concentrations below the EQC proposed in Switzerland. For diclofenac, this is particularly interesting as this compound is now listed on the first watch list of the (EC 2013).

Among the other emerging micropollutants measured, some are listed as priority pollutants (EC 2013). Maximum admissible concentration (MAC-EQS) and annual average environmental quality standards (AA-EQS) have been set up for them in surface waters (supporting material - Table S5). All the compounds with MAC-EQS defined were always quantified below these values in the dissolved phase. For AA-EQS, different cases were encountered: pesticides, t-OP and DEHP were always found below, NP was measured below only after treatment; PFOS and benzo[a]pyrene were still found above after treatment. Bisphenol A and triclosan are not included in (EC 2013), but have EQC proposed by the Swiss Ecotoxicity Centre of EAWAG. Regarding it, bisphenol A was always measured below this criterion, even in influents and before dilution, while triclosan was still measured above its limit value after treatment. However, for these compounds, the campaigns have been performed when the WWTP operated in degraded configuration, what should lead to higher concentrations (Geara-Matta 2012). In addition, the WWTP discharges are diluted in the Seine River.

3. Influence of operation parameters and physico-chemical properties of the compounds

Different types of parameters can influence the adsorption processes (de Ridder et al. 2011, Delgado et al. 2012): structures and properties of the adsorbent, physico-chemical properties of the targeted compounds, water quality and composition and the operation parameters (dose of adsorbent, contact time, etc.). As explained previously, emerging micropollutant removals are lower when the WWTP operates in degraded configuration, because of stronger competition from effluent organic matter and higher concentrations. Results of this study also allow characterizing the relationship between fresh PAC dose and performances, as well as investigating the relations between physico-chemical properties of the compounds and their behaviors with PAC.

\subsection{Operation parameters}

\section{The fresh PAC dose}

To assess the influence of the fresh PAC dose, 4 doses (5-10-20-70 mg/L) were tested during nominal WWTP configuration and the results of the 12 PhPHs quantified in every campaigns of the phase 1 (Figure 4) were considered. 
Based on our results, the fresh PAC dose appears to be the leading operation parameter as regards its influence on performances. In particular, a significant positive correlation is found between the removal of the $26 \mathrm{PhPHs}$ and the dose of PAC $\left(\mathrm{r}_{\text {spearman }}=0.962 ; \mathrm{p}\right.$-value $\left.<0.001 ; \alpha=0.05\right)$ considering the results in nominal WWTP configuration. Similarly, significant correlations are found between their individual removals and the PAC dose, as well as for DOC removal (supporting material - Table S6). In particular, diclofenac, sulfamethoxazole, metronidazole, sulfadiazine, atenolol, propranolol and carbamazepine have all spearman coefficient of correlation higher than 0.8 with p-value lower than 0.05 .

As previously reported (Boehler et al. 2012, Snyder et al. 2007), the higher the PAC dose, the higher the removals. Overall, the point of inflexion is reached around $10 \mathrm{mg} / \mathrm{L}$ for most of the compounds, explaining why the gain of removal is relatively moderate between 10 and $20 \mathrm{mg} / \mathrm{L}$ and between 20 and $70 \mathrm{mg} / \mathrm{L}$ of PAC, despite the strong correlation. In addition, while 9 compounds are very well removed at $10 \mathrm{mg} / \mathrm{L}$ of PAC, they are 14 at $20 \mathrm{mg} / \mathrm{L}$ and 3 at $5 \mathrm{mg} / \mathrm{L}$ (Figure 4). Similarly, the number of well or very well removed compounds increases from 12 at $5 \mathrm{mg} / \mathrm{L} \mathrm{of}$ PAC, to 20 at $10 \mathrm{mg} / \mathrm{L}$ and 26 at $20 \mathrm{mg} / \mathrm{L}$. Finally, applying a high dose of fresh PAC (70 mg/L) enables to achieve a very high elimination of micropollutants, with removals higher than $90 \%$ for all compounds. In particular, diclofenac which is on the first watch list of the (EC 2013), is moderately removed at $5 \mathrm{mg} / \mathrm{L}$ of fresh PAC, well removed at 10 $\mathrm{mg} / \mathrm{L}$ and very well removed at $20 \mathrm{mg} / \mathrm{L}$. Similarly, sulfamethoxazole is very impacted by the PAC dose. Finally, the removal of the total PhPHs concentration is around $76 \%$ at $10 \mathrm{mg} / \mathrm{L}$ of $\mathrm{PAC}, 45 \%$ at $5 \mathrm{mg} / \mathrm{L}$ and $83 \%$ at $20 \mathrm{mg} / \mathrm{L}$.

\section{Total mass of the PAC in the bed}

In normal operation of the pilot, the total mass of the PAC bed is close to $40 \mathrm{~kg}$. Despite substantial variations of the total mass of PAC in the bed (supporting material - Table S1), no significant impact is observed on the performances, highlighting that this parameter is minor. However, the presence of a high mass of PAC in the bed should slightly enhance the performances compared to operating with only the fresh PAC dose, as it was observed with laboratory scale experiments (not presented). This confirms that the observed removals on the pilot are mainly achieved by the fresh PAC dose whereas the quantity of preloaded one in the bed allows a limited enhancement of the overall performances. This observation has to be confirmed by laboratory scale tests in order to clearly identify the role of injected or preloaded PAC.

\section{Other operation parameters}


The hydraulic velocity has theoretically an influence on contact time. Moreover, contact time has been identified as significantly impacting the adsorption process in the literature (Snyder et al. 2007). However, the hydraulic velocity/the water flow has not a significant impact on the observed contact time in the CarboPlus ${ }^{\circledR}$ process because the variation of the hydraulic velocity is coupled with a modification of the bed depth. Indeed, a higher velocity means a higher bed depth by natural expansion, which balances the decrease of contact time. In addition, the experimental design doesn't allow deeply assessing this point, contrary to the PAC dose. Nevertheless, although a slight impact is observed on efficacy for some compounds (supporting material - Figure S4) such as atenolol, diclofenac or oxazepam, it seems that hydraulic velocity would not be a driving parameter of the process efficacy.

Finally, the solid retention time (SRT) of PAC and the presence of coagulant and flocculant were not studied in this paper. (Margot et al. 2013) have nevertheless observed a slight increase of micropollutant removal by PAC adsorption in presence of coagulant.

\subsection{Influence of the physico-chemical properties of the compounds on their removals}

The fate of many pollutants within PAC can be explained by their physico-chemical properties. First of all, the charge of the compound is a crucial parameter in their removal. Indeed, all positively charged compounds (atenolol, propranolol, trimethoprim, ciprofloxacin, norfloxacin) are well removed (>80\%), regardless their other properties. This has already been underlined in the literature (de Ridder et al. 2011, Margot et al. 2013). In fact, depending on the point of zero charge (PZC) of the adsorbent, its surface can be neutral or slightly charged (positively or negatively) at influent $\mathrm{pH}$ (7-8). In addition, sorption of effluent organic matter, generally negatively charged in wastewater, on activated carbon surface can switch (if initially neutral or positive) or increase (if already negative) the charge, resulting overall in a surface negatively charged (Margot et al. 2013, Yu et al. 2012a). Therefore, this indicates that in this case the PAC surface has negative charges inducing strong electrostatic attraction of positive compounds. In spite of their positive charges, erythromycin and roxithromycin are less removed (50-60\%), probably as a results of their high molecular masses (733.5 and $837.0 \mathrm{~g} / \mathrm{mol}$ respectively; supporting material - Table S4), inducing a higher sensibility to competition with organic matter and other compounds ( $\mathrm{Ji}$ et al. 2010), and a size exclusion (Moreno-Castilla et al. 2003). For these compounds, a slight positive relation with hydrophobicity ( $\left.\log \mathrm{D}_{\mathrm{ow}}\right)$ is moreover observed, i.e. atenolol $\left(80 \%-\log \mathrm{D}_{\mathrm{OW}}=-1.99\right)$ vs. propranolol $\left(94 \%-\log \mathrm{D}_{\mathrm{OW}}=0.98\right)$. The number of $\mathrm{H}-$ bond sites and the 
compound structure do not seem to have any substantial influence for these compounds. Moreover, considering only compounds with similar log Dow and molecular mass, negatively charged compounds are less removed than positively charged ones (i.e. trimethoprim, propranolol, naproxen, diclofenac, sulfamethoxazole).

For neutral and negatively charged compounds (Figure 2 and supporting material - Table S3), the hydrophobicity and the structure of the compound seem to play a major role in removal. The influence of hydrophobicity, polarizability or structure of the compound (functional groups allowing H-bond or $\pi-\pi$ binding) has already been reported (de Ridder et al. 2010, Delgado et al. 2012). Indeed, the adsorption of the neutral compounds seems to be influenced by their hydrophobicity, as reflected by a significant positive correlation $\left(\mathrm{r}_{\text {spearman }}=0.587\right.$; $\mathrm{p}$-value $\left.<0.05 ; \alpha=0.05\right)$ found between $\log$ Dow and removals of PhPHs. (Westerhoff et al. 2005) observed a similar trend. In addition to the hydrophobicity, specific interactions between PhPHs functional groups and PAC should be involved. Indeed, (de Ridder et al. 2010) have reported that H-binding and $\pi-\pi$ interactions become very important at low hydrophobicity, inducing possible substantial differences in the fate of compounds with similar hydrophobicity.

No significant or specific relations were found for negative compounds between removal and properties. Hydrophobicity was not identified as enhancing their adsorption, in contrary to what (Margot et al. 2013) observed. Absence of direct relationship between adsorption and hydrophobicity was also observed for some antibiotics by (Ji et al. 2010). These compounds are more likely influenced by their structures and their fates should be driven by a balance between electrostatic repulsion and specific interactions with PAC surface. (Moreno-Castilla et al. 2003) concluded that aromatic compounds are mainly physisorbed on activated carbon, confirming the prevalence of these weak interactions. Some functional groups may enhance adsorption such as aromaticity and N-heterocycles (Delgado et al. 2012), explaining the high removal of ofloxacin although this compound is negatively charged. For instance, ofloxacin and diclofenac have three heterocycles, known to enhance adsorption on activated carbon (Delgado et al. 2012), while sulfamethoxazole and sulfadiazine have only one heterocycle.

\section{CONCLUSIONS}

Among the solutions to reduce the emerging contaminant discharges into the environment, the implementation of a tertiary treatment in actual WWTP is more and more considered. Besides, emerging micropollutants, particularly 
pharmaceuticals, may be included in modifications of existing regulations. For instance, diclofenac, 17- $\alpha-$ and 17- $\beta$ estradiols are now on the first watch list of the (EC 2013), and the Swiss Centre for applied ecotoxicology has proposed environmental quality criteria for several emerging micropollutants.

In this context, the fate of 113 micropollutants within a large scale PAC adsorption pilot (CarboPlus ${ }^{\circledR}$ ) has been studied. 54 pharmaceuticals and hormones (PhPHs) and 59 other micropollutants, such as pesticides, personal care products, phthalates, PAHs or artificial sweeteners, were then monitored. The 14 campaigns performed allowed assessing the overall performances of the process for these compounds, and the influence of the WWTP configuration, the operation parameters and the physico-chemical properties of the micropollutants on the process efficacy.

$26 \mathrm{PhPHs}$ were quantified in influents from nominal WWTP configuration including 8 substances with concentrations higher than $100 \mathrm{ng} / \mathrm{L}$. Sulfamethoxazole is predominant with the highest average concentration, accounting for about $30 \%$ in average of the sum of the 26 PhPHs. In contrary, the remaining molecules were measured whether at low $(<10$ $\mathrm{ng} / \mathrm{L})$, like estrone or lorazepam, or at intermediate concentrations (10-100 ng/L), like naproxen or trimethoprim. 6 of them are poorly or moderately removed by the process $(<60 \%)$, i.e. paracetamol, ibuprofen or sulfamethoxazole, and 11 are rather well removed $(60-80 \%)$, especially diclofenac, naproxen or oxazepam. The 9 remaining substances are very well eliminated (>80\%), i.e. beta blockers, carbamazepine or trimethoprim

The change of the WWTP configuration has a substantial impact on the influents quality (DOC, UV-254, BOD 5 , nitrogen species, TSS) and most of the PhPHs have higher concentrations in this configuration, highlighting both the seasonal variations and the removal performed due to denitrification step in nominal configuration. Paracetamol and ibuprofen concentrations are multiplied by 100 . PhPHs are overall slightly less removed in percentage in this WWTP configuration but a higher flux is eliminated. This is consistent considering the higher concentrations and the degradation of the influents quality which probably enhances the competition effects.

Concentrations of the other micropollutants during degraded WWTP configuration are variable but phthalates and artificial sweeteners are present at very high concentrations, up to 1 000-10 $000 \mathrm{ng} / \mathrm{L}$, bisphenol A and NP between 100 and $1000 \mathrm{ng} / \mathrm{L}$, and pesticides, perfluorinated acids, PAHs and parabens below $100 \mathrm{ng} / \mathrm{L}$. Except parabens and pesticides, which are largely removed (50-95\%), most of the other micropollutants are poorly to moderately removed. However, similarly to PhPHs, it can be assumed that performances would be higher in nominal WWTP configuration for these compounds.

The fresh PAC dose has been identified as the main operation parameter which significantly influences the 
performances for micropollutant removals. The total mass of PAC in the bed was not identified as influencing the performances in the studied range of mass. Overall, in nominal WWTP configuration, the CarboPlus ${ }^{\circledR}$ process reduces in average the sum of the PhPHs of about $53 \%$ at a dose of PAC of $5 \mathrm{mg} / \mathrm{L}, 76 \%$ at $10 \mathrm{mg} / \mathrm{L}$ and more than $83 \%$ at 20 mg/L. Finally, a high dose of PAC allows to achieve very high removals (>90\%) of all the PhPHs, but at higher costs.

The molecular charge seems to be the most important property influencing the fate of micropollutants. However, the size of the molecule can be a limiting factor because high molecular weight compounds are more sensitive to organic matter competition. A higher dose is then needed for heavy compounds compared to others, at comparable other molecular properties. For neutral or negative compounds, hydrophobicity and structure of the molecule, particularly the presence of specific functional groups, become very important in their fates.

This pilot is still operating in 2014, and a new type of activated carbon is tested. This micro-grain activated carbon ( $\mu \mathrm{GAC})$ has an intermediary size between PAC $(<50 \mu \mathrm{m})$ and grain $(>1 \mathrm{~mm})$, that facilitates the bed handling (no need of chemical addition) together with good performances for micropollutants elimination. Moreover, $\mu$ GAC selected is produced from regenerated activated carbon and is regenerated several times, ensuring a reduction of cost and a higher sustainability of the process.

\section{ACKNOWLEDGEMENT}

This study has been performed within the framework of the OPUR research program. The authors would like to thank the SIAAP (Céline Briand and Julien Pouillaude), the LEESU (Damien Lherm), the ISA (Audrey Bulete, Antoine Vauchez, Mikaël Tournier and Loic Spinner) and the SAUR (Séverine Bareilles) teams for their technical support and their active participation to the sampling campaigns. Similarly, authors thank the technical teams of the Technological University of Compiègne (UTC) and the Water Technology Centre (TZW) for their participation in analyses. 


\section{REFERENCES}

Abegglen, C. and Siegrist, H. (2012) Micropolluants dans les eaux résiduaires urbaines. Etapes de traitement supplémentaire dans les stations d'épuration. (in French). Environment, S.F.o.f.t. (ed), p. 87 .

Altmann, J., Ruhl, A.S., Zietzschmann, F. and Jekel, M. (2014) Direct comparison of ozonation and adsorption onto powdered activated carbon for micropollutant removal in advanced wastewater treatment. Water Research 55(0), 185-193. Barrek, S., Cren-olivé, C., Wiest, L., Baudot, R., Arnaudguilhem, C. and Grenier-Loustalot, M.-F. (2009) Multi-residue analysis and ultra-trace quantification of 36 priority substances from the European Water Framework Directive by GC-MS and LC-FLD-MS/MS in surface waters. Talanta 79(3), 712-722. Bergé, A., Cladière, M., Gasperi, J., Coursimault, A., Tassin, B. and Moilleron, R. (2013) Meta-analysis of environmental contamination by phthalates. Environmental Science and Pollution Research, 1-20.

Bergé, A., Gasperi, J., Rocher, V., Gras, L., Coursimault, A. and Moilleron, R. (2014) Phthalates and alkylphenols in industrial and domestic effluents: Case of Paris conurbation (France). Science of the Total Environment 488-489(0), 26-35. Berset, J.-D. and Ochsenbein, N. (2012) Stability considerations of aspartame in the direct analysis of artificial sweeteners in water samples using highperformance liquid chromatography-tandem mass spectrometry (HPLC-MS/MS). Chemosphere $88(5), 563-569$.

Boehler, M., Zwickenpflug, B., Hollender, J., Ternes, T., Joss, A. and Siegrist, H. (2012) Removal of micropollutants in municipal wastewater treatment plants by powder-activated carbon, International Water Association, London, Royaume-Uni. Bolong, N., Ismail, A.F., Salim, M.R. and Matsuura, T. (2009) A review of the effects of emerging contaminants in wastewater and options for their removal. Desalination $239(1-3), 229-246$.

Bressy, A., Gromaire, M.C., Lorgeoux, C., Saad, M., Leroy, F. and Chebbo, G. (2012) 'Towards the determination of an optimal scale for stormwater quality management: Micropollutants in a small residential catchment. Water Research $46(20), 6799-6810$.

Çeçen, F. and Aktas, Ö. (2012) Activated carbon for water and wastewater treatment integration of adsorption and biological treatment, Wiley-VCH, Weinheim, Germany.

Chen, Z.-F., Ying, G.-G., Lai, H.-J., Chen, F., Su, H.-C., Liu, Y.-S., Peng, F.Q. and Zhao, J.-L. (2012) Determination of biocides in different environmental matrices by use of ultra-high-performance liquid chromatography-tandem mass spectrometry. Analytical and Bioanalytical Chemistry 404(10), 3175-3188. Clara, M., Strenn, B., Gans, O., Martinez, E., Kreuzinger, N. and Kroiss, H. (2005) Removal of selected pharmaceuticals, fragrances and endocrine disrupting compounds in a membrane bioreactor and conventional wastewater treatment plants. Water Research 39(19), 4797-4807.

Clara, M., Scharf, S., Scheffknecht, C. and Gans, O. (2007) Occurrence of selected surfactants in untreated and treated sewage. Water Research 41 , $4339-$ 4348 .

Daughton, C.G. and Ternes, T.A. (1999) Pharmaceuticals and personal care products in the environment: Agents of subtle change? Environmental Health Perspectives $107,907-938$.

de Ridder, D.J., Villacorte, L., Verliefde, A.R.D., Verberk, J.Q.J.C., Heijman, S.G.J., Amy, G.L. and van Dijk, J.C. (2010) Modeling equilibrium adsorption of organic micropoliutants onto activated carbon. Water Research 44(10), 3077-3086. de Ridder, D.J., Verliefde, A.R., Heijman, S.G., Verberk, J.Q., Rietveld, L.C., van der Aa, L.T., Amy, G.L. and van Dijk, J.C. (2011) Influence of natural organic matter on equilibrium adsorption of neutral and charged pharmaceuticals onto activated carbon. Water Sci Technol 63 (3), 416-423. de Ridder, D.J., Verliefde, A.R.D., Schoutteten, K., van der Linden, B., Heijman, S.G.J., Beurroies, I., Denoyel, R. , Amy, G.L. and van Dijk, J.C. (2013) Relation between interfacial energy and adsorption of organic micropollutants onto activated carbon. Carbon 53(0), 153-160.

Deblonde, T., Cossu-Leguille, C. and Hartemann, P. (2011) Emerging pollutants in wastewater: A review of the literature. International Journal of Hygiene and Environmental Health 214(6), 442-448.

Delgado, L.F., Charles, P., Glucina, K. and Morlay, C. (2012) The removal of endocrine disrupting compounds, pharmaceutically activated compounds and cyanobacterial toxins during drinking water preparation using activated carbonA review. Science of the Total Environment 435-436(0), 509-525. Ebie, K., Li, F., Azuma, Y., Yuasa, A. and Hagishita, T. (2001) Pore distribution effect of activated carbon in adsorbing organic micropollutants 
from natural water. Water Research 35(1), 167-179. EC (2013) Directive 2013/39/EU of the European Parliament amending Directives $2000 / 60 / \mathrm{EC}$ and 2008/105/EC as regards priority substances in the field of water policy. JO-EU L226/1.

Fatone, F., Di Fabio, S., Bolzonella, D. and Cecchi, F. (2011) Fate of aromatic hydrocarbons in Italian municipal wastewater systems: An overview of wastewater treatment using conventional activated-sludge processes (CASP) and membrane bioreactors (MBRs). Water Research 45(1), 93-104.

Gasperi, J., Kafi-Benyahia, M., Lorgeoux, C., Moilleron, R., Gromaire, M.C. and Chebbo, G. (2008) Wastewater quality and pollutant loads in combined sewers during dry weather periods. Urban Water Journal 5(4), 305-314.

Gasperi, J., Geara, D., Lorgeoux, C., Bressy, A., Zedek, S., Rocher, V., El Samrani, A., Chebbo, G. and Moilleron, R. (2014) First assessment of triclosan, triclocarban and paraben mass loads at a very large regional scale: Case of Paris conurbation (France). Science of the Total Environment 493(0), 854-861. Geara-Matta, D. (2012) Flux and sources of parabens, triclosan and triclocarban in dense urban areas: comparison between Paris and Beyrouth (in French), Ecole des Ponts ParisTech.

Götz, C., Stamm, C., Fenner, K., Singer, H., Schärer, M. and Hollender, J. (2010) Targeting aquatic microcontaminants for monitoring: exposure categorization and application to the Swiss situation. Environmental science and Pollution Research $17(2), 341-354$.

Halling-Sørensen, B., Nors Nielsen, S., Lanzky, P.F., Ingerslev, F., Holten Lützhøft, H.C. and Jørgensen, S.E. (1998) Occurrence, fate and effects of pharmaceutical substances in the environment- A review. Chemosphere 36(2), 357393.

Heberer, T. (2002) Occurrence, fate, and removal of pharmaceutical residues in the aquatic environment: a review of recent research data. Toxicology Letters $131(1-2), 5-17$.

Ji, L., Liu, F., Xu, Z., Zheng, S. and Zhu, D. (2010) Adsorption of

Pharmaceutical Antibiotics on Template-Synthesized Ordered Micro- and Mesoporous Carbons. Environmental Science \& Technology 44(8), 3116-3122.

Jones, O.A.H., Voulvoulis, N. and Lester, J.N. (2001) Human Pharmaceuticals in the Aquatic Environment a Review. Environmental Technology 22(12), 1383-1394. Joss, A., Keller, E., Alder, A.C., Göbel, A., McArdell, C.S., Ternes, T. and Siegrist, H. (2005) Removal of pharmaceuticals and fragrances in biological wastewater treatment. Water Research 39(14), 3139-3152.

Joss, A., Siegrist, H. and Ternes, T.A. (2008) Are we about to upgrade wastewater treatment for removing organic micropollutants? Water Sci Technol $57(2), 251-255$.

Kase, R., Eggen, R.I.L., Junghans, M., Götz, C. and Hollender, J. (2011) Waste Water - Evaluation and Management. Einschlag, P.F.S.G. (ed), InTech. Lange, F., Scheurer, M. and Brauch, H.-J. (2012) Artificial sweeteners-a recently recognized class of emerging environmental contaminants: a review. Analytical and Bioanalytical Chemistry 403(9), 2503-2518.

Loos, R., Carvalho, R., António, D.C., Comero, S., Locoro, G., Tavazzi, S., Paracchini, B., Ghiani, M., Lettieri, T., Blaha, L., Jarosova, B., Voorspoels, S., Servaes, K., Haglund, P., Fick, J., Lindberg, R.H., Schwesig, D. and Gawlik, B.M. (2013) EU-wide monitoring survey on emerging polar organic contaminants in wastewater treatment plant effluents. Water Research 47(17), 6475-6487.

Löwenberg, J., Zenker, A., Baggenstos, M., Koch, G., Kazner, C. and Wintgens, T. (2014) Comparison of two PAC/UF processes for the removal of micropollutants from wastewater treatment plant effluent: Process performance and removal efficiency. Water Research 56(0), 26-36.

Luo, Y., Guo, W., Ngo, H.H., Nghiem, L.D., Hai, F.I., Zhang, J., Liang, S. and Wang, X.C. (2014) A review on the occurrence of micropollutants in the aquatic environment and their fate and removal during wastewater treatment. Science of the Total Environment 473-474(0), 619-641.

Mailler, R., Gasperi, J., Rocher, V., Gilbert-Pawlik, S., Geara-Matta, D., Moilleron, R. and Chebbo', G. (2013) Biofiltration vs conventional activated sludge plants: what about priority and emerging pollutants removal? Environmental Science and Pollution Research, 1-12.

Margot, J., Kienle, C., Magnet, A., Weil, M., Rossi, L., de Alencastro, L.F., Abegglen, C., Thonney, D., Chèvre, N., Schärer, M. and Barry, D.A. (2013) Treatment of micropoliutants in municipal wastewater: Ozone or powdered activated carbon? Science of the Total Environment 461-462(0), 480-498. McAdam, E.J., Bagnall, J.P., Koh, Y.K.K., Chiu, T.Y., Pollard, S., Scrimshaw, M.D., Lester, J.N. and Cartmell, E. (2010) Removal of steroid estrogens in carbonaceous and nitrifying activated sludge processes. Chemosphere 81(1), 1-6. 
Miège, C., Choubert, J.M., Ribeiro, L., Eusèbe, M. and Coquery, M. (2009) Fate of pharmaceuticals and personal care products in wastewater treatment plants Conception of a database and first results. Environmental pollution 157(5), 1721-1726.

Moreno-Castilla, C., Bautista-Toledo, I., Ferro-Garcia, M.A. and Rivera-Utrilla, J. (2003) Influence of support surface properties on activity of bacteria immobilised on activated carbons for water denitrification. Carbon 41, 17431749 .

Ordóñez, E.Y., Quintana, J.B., Rodil, R. and Cela, R. (2012) Determination of artificial sweeteners in water samples by solid-phase extraction and liquid chromatography-tandem mass spectrometry. Journal of Chromatography A 1256(0), 197-205.

Qiao, M., Qi, W., Liu, H. and Qu, J. (2014) Occurrence, behavior and removal of typical substituted and parent polycyclic aromatic hydrocarbons in a biological wastewater treatment plant. Water Research 52(0), 11-19.

Radjenović, J., Petrović, M. and Barceló, D. (2009) Fate and distribution of pharmaceuticals in wastewater and sewage sludge of the conventional activated sludge (CAS) and advanced membrane bioreactor (MBR) treatment. Water Research $43(3), 831-841$.

Rocher, V., Paffoni, C., Goncalves, A., Guerin, S., Azimi, S., Gasperi, J., Moilleron, R. and Pauss, A. (2012) Municipal wastewater treatment by biofiltration: comparisons of various treatment layouts. Part 1: assessment of carbon and nitrogen removal. Water Science and Technology 65(9), 1705-1712. Ruel, S.M., Choubert, J.M., Esperanza, M., Miege, C., Navalon Madrigal, P., Budzinski, H., Le Menach, K., Lazarova, V. and Coquery, M. (2011) On-site evaluation of the removal of 100 micro-pollutants through advanced wastewater treatment processes for reuse applications. Water Science and Technology 63(11), $2486-2497$.

Ruel, S.M., Choubert, J.M., Budzinski, H., Miege, C., Esperanza, M. and Coquery, M. (2012) Occurrence and fate of relevant substances in wastewater treatment plants regarding Water Framework Directive and future legislations. Water Science and Technology 65(7), 1179-1189.

Sánchez-Avila, J., Fernandez-Sanjuan, M., Vicente, J. and Lacorte, S. (2011) Development of a multi-residue method for the determination of organic micropollutants in water, sediment and mussels using gas chromatography-tandem mass spectrometry. Journal of Chromatography A 1218(38), 6799-6811.

Scheurer, M., Brauch, H.-J. and Lange, F. (2009) Analysis and occurrence of seven artificial sweeteners in German waste water and surface water and in soil aquifer treatment (SAT). Analytical and Bioanalytical Chemistry 394(6), 15851594 .

Scheurer, M., Storck, F.R., Brauch, H.-J. and Lange, F.T. (2010) Performance of conventional multi-barrier drinking water treatment plants for the removal of four artificial sweeteners. Water Research 44(12), 3573-3584.

Snyder, S.A., Adham, S., Redding, A.M., Cannon, F.S., DeCarolis, J., Oppenheimer, J., Wert, E.C. and Yoon, Y. (2007) Role of membranes and activated carbon in the removal of endocrine disruptors and pharmaceuticals. Desalination $202(1-3), 156-181$.

Vulliet, E., Cren-Olivé, C. and Grenier-Loustalot, M.-F. (2011) Occurrence of pharmaceuticals and hormones in drinking water treated from surface waters. Environmental Chemistry Letters 9(1), 103-114.

Westerhoff, P., Yoon, Y., Snyder, S. and Wert, E. (2005) Fate of EndocrineDisruptor, Pharmaceutical, and Personal Care Product Chemicals during Simulated Drinking Water Treatment Processes. Environmental Science \& Technology 39(17), $6649-6663$.

Yu, J., Lv, L., Lan, P., Zhang, S., Pan, B. and Zhang, W. (2012a) Effect of effluent organic matter on the adsorption of perfluorinated compounds onto activated carbon. Journal of Hazardous Materials 225-226(0), 99-106.

Yu, K., Li, B. and Zhang, T. (2012b) Direct rapid analysis of multiple PPCPs in municipal wastewater using ultrahigh performance liquid chromatography-tandem mass spectrometry without SPE pre-concentration. Analytica Chimica Acta 738(0), $59-68$.

Yu, Z., Peldszus, S. and Huck, P.M. (2008) Adsorption characteristics of selected pharmaceuticals and an endocrine disrupting compound-Naproxen, carbamazepine and nonylphenol-on activated carbon. Water Research 42(12), 28732882 .

Zareitalabad, P., Siemens, J., Hamer, M. and Amelung, W. (2013)

Perfluorooctanoic acid (PFOA) and perfluorooctanesulfonic acid (PFOS) in surface waters, sediments, soils and wastewater - A review on concentrations and distribution coefficients. Chemosphere 91(6), 725-732. 
826

827

828 


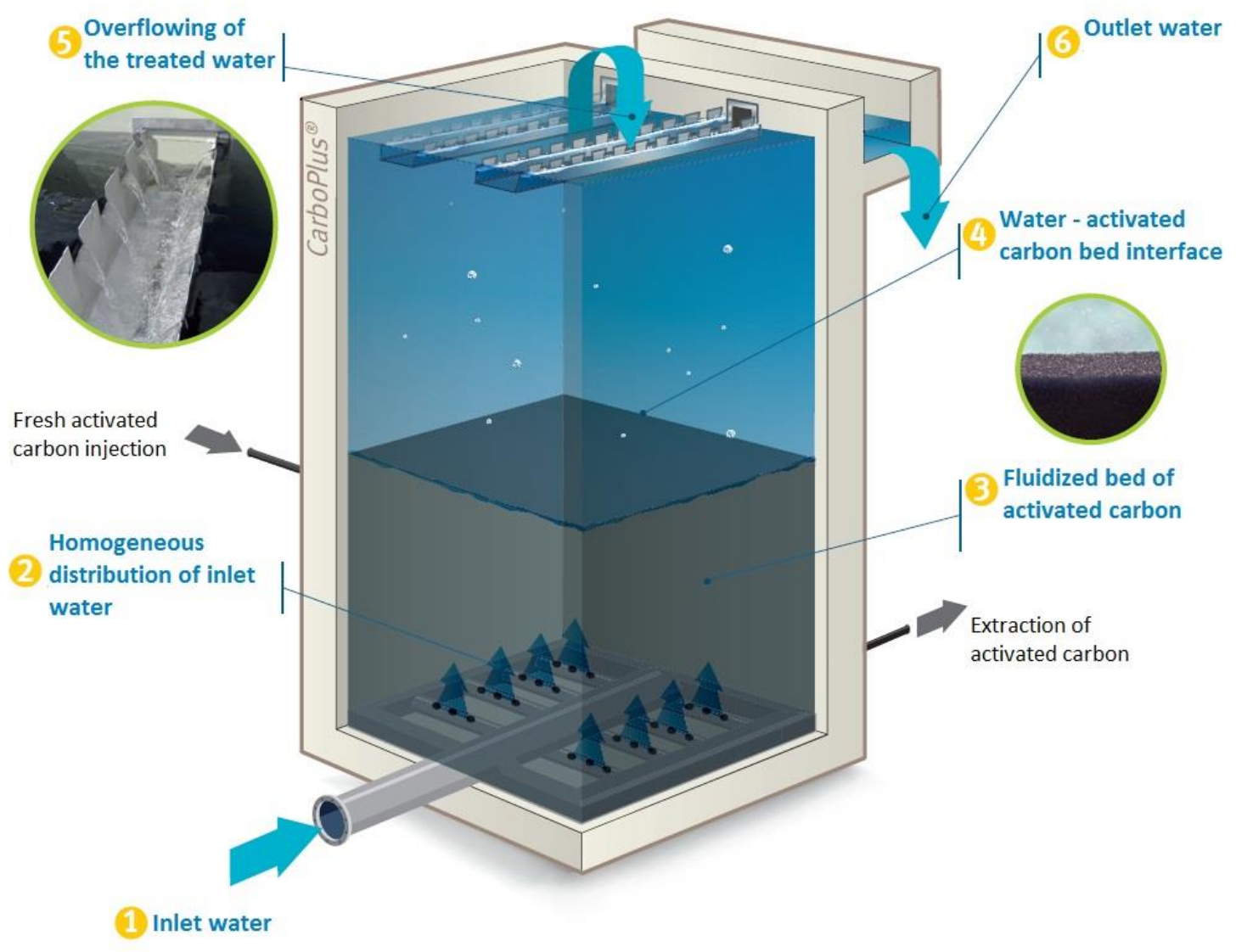

Figure 1 - Layout of the $20 \mathrm{~m}^{3}\left(5 \mathrm{~m} \times 4 \mathrm{~m}^{2}\right)$ CarboPlus ${ }^{\circledR}$ pilot (SAUR source) 
Table 1 - Operation parameters for the 14 campaigns performed

\begin{tabular}{|c|c|c|c|c|c|}
\hline & Date & WWTP configuration & PAC dose & Hydraulic velocity & Total PAC mass $(\mathrm{kg})$ \\
\hline $\mathrm{C} 1 *$ & $02 / 07 / 13$ & \multirow{9}{*}{ Nominal } & 70 & \multirow{3}{*}{8} & \multirow{8}{*}{-} \\
\hline $\mathrm{C} 2$ & $09 / 07 / 13$ & & 20 & & \\
\hline C3 & $16 / 07 / 13$ & & \multirow{2}{*}{5} & & \\
\hline $\mathrm{C} 4$ & $23 / 07 / 13$ & & & 10 & \\
\hline $\mathrm{C} 5$ & $30 / 07 / 13$ & & 20 & \multirow{3}{*}{6} & \\
\hline C6 & $06 / 08 / 13$ & & \multirow{2}{*}{10} & & \\
\hline $\mathrm{C} 7$ & $20 / 08 / 13$ & & & & \\
\hline $\mathrm{C} 8$ & $27 / 08 / 13$ & & 5 & 8 & \\
\hline C9 & $04 / 11 / 13$ & & 10 & 7 & 62 \\
\hline $\mathrm{C} 10$ & $19 / 11 / 13$ & \multirow{5}{*}{ Degraded } & \multirow{5}{*}{10} & \multirow{5}{*}{7} & 46 \\
\hline $\mathrm{C} 11$ & $27 / 11 / 13$ & & & & 52 \\
\hline $\mathrm{C} 12$ & $03 / 12 / 13$ & & & & 53 \\
\hline $\mathrm{C} 13$ & $10 / 12 / 13$ & & & & 45 \\
\hline C14 & $17 / 12 / 13$ & & & & 58 \\
\hline
\end{tabular}


Table 2 - Pollutants studied and their analytical methods

\begin{tabular}{|c|c|c|c|c|c|c|}
\hline Groups & $\mathbf{N}^{\mathbf{a}}$ & $\mathrm{n}^{\mathbf{b}}$ & Reference & Extraction $^{\mathrm{c}}$ & Analysis $^{d}$ & $\mathbf{L Q}^{\mathrm{e}}$ \\
\hline Antibiotics & 31 & 14 & \multirow{6}{*}{ (Vulliet et al. 2011) } & & \multirow{6}{*}{ LC-MSMS } & $0.2-110$ \\
\hline Analgesic & 5 & 14 & & SPE & & $0.04-1.0$ \\
\hline Beta blockers & 2 & 14 & & Autotrace ${ }^{\circledR}$ & & 0.02 \\
\hline Anxiolytics & 4 & 14 & & Strata ${ }^{\circledR}$ or Oasis $H L B \circledast$ & & $1.0-2.0$ \\
\hline Hypolipemiants & 2 & 14 & & cartridges & & $0.7-2.4$ \\
\hline Hormones & 10 & 14 & & & & 1.0 \\
\hline Chlorinated solvents & 3 & 5 & (Barrek et al. 2009) & \multirow{5}{*}{$\begin{array}{c}\text { SPE } \\
\text { Autotrace }{ }^{\circledR} \\
\text { StrataX }{ }^{\circledR} \text { cartridges }\end{array}$} & GC-MS & $0.2-23$ \\
\hline Perfluorinated acids & 2 & 5 & (Vulliet et al. 2011) & & LC-MSMS & 1.0 \\
\hline Pesticides / herbicides & 23 & & & & GC-MS & $6-177$ \\
\hline / insecticides & 23 & 5 & (Barrek et al. 2009) & & LC-MSMS & 0.2 \\
\hline Bisphenol A & 1 & 5 & (Vulliet et al. 2011) & & LC-MSMS & 10 \\
\hline PAHs $^{\mathrm{f}}$ & 13 & 3 & (Bressy et al. 2012) & \multirow{4}{*}{$\begin{array}{c}\text { SPE } \\
\text { Manual } \\
\text { Oasis } H L B \circledR \text { cartridges }\end{array}$} & \multirow{3}{*}{ GC-MS } & 0.2 \\
\hline Alkylphenols & 2 & 5 & (Bergé et al. 2014) & & & $0.6-100$ \\
\hline Phthalates & 4 & 5 & (Bergé et al. 2014) & & & 100 \\
\hline PCPs ${ }^{f}$ & 7 & 3 & (Gasperi et al. 2014) & & LC-MSMS & $2.8-10$ \\
\hline Sweeteners & 4 & 4 & (Scheurer et al. 2009) & $\begin{array}{c}\text { SPE } \\
\text { Autotrace }{ }^{\circledR} \\
\text { Bakerbond SDBl cartridges }\end{array}$ & LC-MSMS & $50-250$ \\
\hline Total micropollutants & \multicolumn{6}{|c|}{ 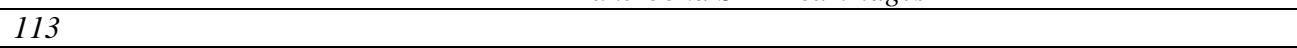 } \\
\hline \multicolumn{7}{|c|}{$\begin{array}{l}{ }^{a} \mathrm{~N}=\text { number of substances. } \\
\text { b } \mathrm{n}=\text { number of campaigns performed. } \\
{ }^{\mathrm{c}} \mathrm{SPE}=\text { solid phase extraction. } \\
\text { d Analytical methods: } \mathrm{LC}=\text { liquid chromatography, GC = gas chromatography, GC-MS = GC with mass spectrometry, LC-MSMS } \\
\text { = LC with tandem mass spectrometry. } \\
\text { e } \mathrm{LQ}=\text { limit of quantification. } \\
\text { f } \mathrm{PAHs}=\text { polycyclic aromatic hydrocarbons; PCPs = personal care products. }\end{array}$} \\
\hline
\end{tabular}


Table 3 - Micropollutant and conventional wastewater parameter concentrations in influents and effluents during nominal and degraded WWTP configuration

\begin{tabular}{|c|c|c|c|c|c|c|c|c|c|}
\hline & \multirow{3}{*}{$\begin{array}{c}\text { LQ } \\
(\mathrm{ng} / \mathrm{L})\end{array}$} & \multicolumn{4}{|c|}{$\begin{array}{l}\text { Nominal WWTP configuration } \\
(\mathrm{n}=9)\end{array}$} & \multicolumn{4}{|c|}{$\begin{array}{c}\text { Degraded WWTP configuration } \\
(\mathrm{n}=5)\end{array}$} \\
\hline & & \multicolumn{2}{|r|}{ Influent } & \multicolumn{2}{|c|}{ Effluent } & \multicolumn{2}{|r|}{ Influent } & \multicolumn{2}{|c|}{ Effluent } \\
\hline & & $\mathrm{N}$ & $\begin{array}{c}\text { Concentration } \\
(\mathrm{ng} / \mathrm{L}) \\
A v . \pm S D \\
(\min -\max ) \\
\end{array}$ & $\mathrm{N}$ & $\begin{array}{c}\text { Concentration } \\
\text { (ng/L) } \\
A v . \pm S D \\
(\text { min }- \text { max }) \\
\end{array}$ & $\mathrm{N}$ & $\begin{array}{c}\text { Concentration } \\
(\text { ng/L) } \\
A v . \pm S D \\
(\min -\max ) \\
\end{array}$ & $\mathrm{N}$ & $\begin{array}{c}\text { Concentration } \\
\text { (ng/L) } \\
A v . \pm S D \\
(\min -\max ) \\
\end{array}$ \\
\hline \multicolumn{10}{|c|}{ Conventional wastewater parameters } \\
\hline UV $254 \mathrm{~nm}\left(\mathrm{~cm}^{-1}\right)$ & 0.01 & $9 / 9$ & $\begin{array}{c}0.110 \pm 0.013 \\
(0.087-0.120)\end{array}$ & $9 / 9$ & $\begin{array}{c}0.075 \pm 0.020 \\
(0.047-0.106) \\
\end{array}$ & $5 / 5$ & $\begin{array}{c}0.139 \pm 0.011 \\
(0.126-0.152)\end{array}$ & $5 / 5$ & $\begin{array}{c}0.109 \pm 0.008 \\
(0.099-0.120) \\
\end{array}$ \\
\hline $\mathrm{DOC}(\mathrm{mgC} / \mathrm{L})$ & 0.5 & $9 / 9$ & $\begin{array}{c}5.6 \pm 0.9 \\
(4.4-7.0) \\
\end{array}$ & $9 / 9$ & $\begin{array}{c}3.5 \pm 1.2 \\
(1.2-5.2) \\
\end{array}$ & $5 / 5$ & $\begin{array}{c}7.5 \pm 0.5 \\
(7.1-8.3) \\
\end{array}$ & $5 / 5$ & $\begin{array}{c}5.8 \pm 0.4 \\
(5.4-6.4) \\
\end{array}$ \\
\hline $\mathrm{COD}\left(\mathrm{mgO}_{2} / \mathrm{L}\right)$ & 4 & $9 / 9$ & $\begin{array}{c}26 \pm 11 \\
(17-47)\end{array}$ & $9 / 9$ & $\begin{array}{c}34 \pm 22 \\
(13-74) \\
\end{array}$ & $5 / 5$ & $\begin{array}{c}26 \pm 2 \\
(23-28)\end{array}$ & $5 / 5$ & $\begin{array}{c}21 \pm 2 \\
(19-25)\end{array}$ \\
\hline $\mathrm{BOD}_{5}\left(\mathrm{mgO}_{2} / \mathrm{L}\right)$ & 0.5 & $9 / 9$ & $\begin{array}{c}4.8 \pm 3.3 \\
(2.8-11.0)\end{array}$ & $9 / 9$ & $\begin{array}{c}3.5 \pm 1.9 \\
(1.3-7.0)\end{array}$ & $5 / 5$ & $\begin{array}{c}5.8 \pm 0.9 \\
(4.9-7.0)\end{array}$ & $5 / 5$ & $\begin{array}{c}3.0 \pm 0.5 \\
(2.4-3.7)\end{array}$ \\
\hline $\mathrm{NH}_{4}^{+}(\mathrm{mgN} / \mathrm{L})$ & 0.3 & $0 / 9$ & $<\mathrm{LQ}$ & $0 / 9$ & $<\mathrm{LQ}$ & $5 / 5$ & $\begin{array}{c}4.4 \pm 0.7 \\
(3.2-5.0)\end{array}$ & $5 / 5$ & $\begin{array}{l}3.5 \pm 0.5 \\
(2.9-4.0)\end{array}$ \\
\hline $\mathrm{NO}_{2}^{-}(\mathrm{mgN} / \mathrm{L})$ & 0.02 & $9 / 9$ & $\begin{array}{c}0.21 \pm 0.17 \\
(0.06-0.23)\end{array}$ & $8 / 9$ & $\begin{array}{c}0.15 \pm 0.16 \\
(<L Q-0.30)\end{array}$ & $5 / 5$ & $\begin{array}{c}0.7 \pm 0.02 \\
(0.05-0.09)\end{array}$ & $5 / 5$ & $\begin{array}{c}0.29 \pm 0.16 \\
(0.03-0.46)\end{array}$ \\
\hline $\mathrm{NO}_{3}^{-}(\mathrm{mgN} / \mathrm{L})$ & 0.4 & $9 / 9$ & $\begin{array}{c}9.1 \pm 2.9 \\
(5.6-11.7)\end{array}$ & $9 / 9$ & $\begin{array}{c}8.5 \pm 2.8 \\
(4.9-13.7) \\
\end{array}$ & $5 / 5$ & $\begin{array}{c}23.7 \pm 2.1 \\
(20.6-25.4)\end{array}$ & $5 / 5$ & $\begin{array}{c}24.4 \pm 2.5 \\
(20.7-26.6)\end{array}$ \\
\hline $\mathrm{TKN}(\mathrm{mgN} / \mathrm{L})$ & 0.5 & $9 / 9$ & $\begin{array}{c}1.5 \pm 0.2 \\
(1.1-1.8)\end{array}$ & $9 / 9$ & $\begin{array}{c}1.2 \pm 0.1 \\
(0.9-1.3)\end{array}$ & $5 / 5$ & $\begin{array}{c}4.9 \pm 0.5 \\
(4.1-5.5)\end{array}$ & $5 / 5$ & $\begin{array}{c}3.9 \pm 0.4 \\
(3.4-4.4)\end{array}$ \\
\hline $\mathrm{PO}_{4}{ }^{3-}(\mathrm{mgP} / \mathrm{L})$ & 0.1 & $0 / 5$ & $<\mathrm{LQ}$ & $0 / 5$ & $<\mathrm{LQ}$ & $0 / 5$ & $<\mathrm{LQ}$ & $0 / 5$ & $<\mathrm{LQ}$ \\
\hline $\mathrm{TP}(\mathrm{mgP} / \mathrm{L})$ & 0.3 & $0 / 5$ & $<\mathrm{LQ}$ & $0 / 5$ & $<\mathrm{LQ}$ & $0 / 5$ & $<\mathrm{LQ}$ & $0 / 5$ & $<\mathrm{LQ}$ \\
\hline TSS (mg/L) & 2.0 & $9 / 9$ & $\begin{array}{c}3 \pm 1 \\
(2-5)\end{array}$ & $9 / 9$ & $\begin{array}{c}9 \pm 7 \\
(2-21)\end{array}$ & $5 / 5$ & $\begin{array}{c}6 \pm 2 \\
(4-9) \\
\end{array}$ & $5 / 5$ & $\begin{array}{l}5 \pm 2 \\
(2-6)\end{array}$ \\
\hline \multicolumn{10}{|c|}{ Pharmaceuticals and hormones } \\
\hline Ketoprofen & 0.3 & $9 / 9$ & $\begin{array}{c}34 \pm 18 \\
(13-61) \\
\end{array}$ & $6 / 9$ & $\begin{array}{c}11 \pm 10 \\
(<L Q-30)\end{array}$ & $5 / 5$ & $\begin{array}{c}367 \pm 90 \\
(273-501)\end{array}$ & $5 / 5$ & $\begin{array}{c}145 \pm 28 \\
(109-182) \\
\end{array}$ \\
\hline Naproxen & 0.7 & $8 / 8$ & $\begin{array}{l}33 \pm 28 \\
(8-83)\end{array}$ & $5 / 8$ & $\begin{array}{c}12 \pm 13 \\
(<L Q-34)\end{array}$ & $5 / 5$ & $\begin{array}{c}154 \pm 39 \\
(122-220)\end{array}$ & $5 / 5$ & $\begin{array}{c}52 \pm 9 \\
(43-64) \\
\end{array}$ \\
\hline Paracetamol & 0.04 & $6 / 9$ & $\begin{array}{c}33 \pm 22 \\
(<L Q-70)\end{array}$ & $6 / 9$ & $\begin{array}{c}32 \pm 18 \\
(<L Q-56)\end{array}$ & $5 / 5$ & $\begin{array}{c}5870 \pm 2597 \\
(3610-10350) \\
\end{array}$ & $5 / 5$ & $\begin{array}{c}1030 \pm 923 \\
(349-2650) \\
\end{array}$ \\
\hline Ibuprofen & 1.0 & $2 / 9$ & $\begin{array}{c}9 \\
(<L Q-13) \\
\end{array}$ & $5 / 9$ & $\begin{array}{c}9 \pm 5 \\
(<L Q-14) \\
\end{array}$ & $5 / 5$ & $\begin{array}{c}951 \pm 360 \\
(590-1439) \\
\end{array}$ & $5 / 5$ & $\begin{array}{c}432 \pm 200 \\
(220-699) \\
\end{array}$ \\
\hline Diclofenac & 0.3 & $9 / 9$ & $\begin{array}{c}184 \pm 91 \\
(95-309)\end{array}$ & $9 / 9$ & $\begin{array}{c}52 \pm 51 \\
(3-166) \\
\end{array}$ & $5 / 5$ & $\begin{array}{c}384 \pm 76 \\
(301-508)\end{array}$ & $5 / 5$ & $\begin{array}{c}171 \pm 19 \\
(147-196)\end{array}$ \\
\hline Sulfamethoxazole & 1.0 & $9 / 9$ & $\begin{array}{c}993 \pm 817 \\
(175-3010) \\
\end{array}$ & $9 / 9$ & $\begin{array}{l}419 \pm 318 \\
(37-798) \\
\end{array}$ & $5 / 5$ & $\begin{array}{l}233 \pm 179 \\
(70-470)\end{array}$ & $3 / 5$ & $\begin{array}{c}130 \\
(<L Q-235)\end{array}$ \\
\hline Ofloxacin & 10 & $9 / 9$ & $\begin{array}{l}412 \pm 314 \\
(14-911) \\
\end{array}$ & $8 / 9$ & $\begin{array}{c}70 \pm 74 \\
(<L Q-218) \\
\end{array}$ & $5 / 5$ & $\begin{array}{c}39 \pm 7 \\
(34-51) \\
\end{array}$ & $3 / 5$ & $\begin{array}{c}18 \\
(<L Q-24) \\
\end{array}$ \\
\hline Ciprofloxacin & 1.0 & $8 / 9$ & $\begin{array}{c}175 \pm 93 \\
(64-312) \\
\end{array}$ & $6 / 9$ & $\begin{array}{c}22 \pm 17 \\
(<L Q-51)\end{array}$ & $5 / 5$ & $\begin{array}{c}13 \pm 3 \\
(11-17) \\
\end{array}$ & $3 / 5$ & $\begin{array}{c}5 \\
(<L Q-8) \\
\end{array}$ \\
\hline Trimethoprim & 0.3 & $9 / 9$ & $\begin{array}{c}64 \pm 79 \\
(8-222) \\
\end{array}$ & $8 / 9$ & $\begin{array}{c}4 \pm 2 \\
(<L Q-8)\end{array}$ & $5 / 5$ & $\begin{array}{l}43 \pm 28 \\
(9-74) \\
\end{array}$ & $4 / 5$ & $\begin{array}{c}6 \pm 3 \\
(<L Q-9)\end{array}$ \\
\hline Metronidazole & 0.2 & $9 / 9$ & $\begin{array}{c}19 \pm 3 \\
(15-24)\end{array}$ & $8 / 9$ & $\begin{array}{c}8 \pm 3 \\
(<L Q-12)\end{array}$ & $5 / 5$ & $\begin{array}{c}30 \pm 4 \\
(23-33) \\
\end{array}$ & $5 / 5$ & $\begin{array}{c}25 \pm 4 \\
(18-29) \\
\end{array}$ \\
\hline Roxithromycin & 1.0 & $4 / 4$ & $\begin{array}{c}99 \pm 53 \\
(57-173) \\
\end{array}$ & $4 / 4$ & $\begin{array}{l}35 \pm 33 \\
(5-76) \\
\end{array}$ & $5 / 5$ & $\begin{array}{c}175 \pm 59 \\
(126-271) \\
\end{array}$ & $4 / 5$ & $\begin{array}{c}99 \pm 42 \\
(<L Q-155)\end{array}$ \\
\hline Norfloxacin & 1.0 & $5 / 9$ & $\begin{array}{c}80 \pm 36 \\
(<L Q-118)\end{array}$ & $3 / 9$ & $\begin{array}{c}17 \\
(<L Q-29) \\
\end{array}$ & $0 / 5$ & $<\mathrm{LQ}$ & $0 / 5$ & $<\mathrm{LQ}$ \\
\hline Erythromycin & 1.0 & $4 / 4$ & $\begin{array}{c}124 \pm 32 \\
(97-170) \\
\end{array}$ & $4 / 4$ & $\begin{array}{c}50 \pm 38 \\
(23-106)\end{array}$ & $0 / 5$ & $<\mathrm{LQ}$ & $0 / 5$ & $<\mathrm{LQ}$ \\
\hline Sulfadimerazine & 1.0 & $2 / 9$ & $\begin{array}{c}4 \\
(<L Q-7)\end{array}$ & $1 / 9$ & $(<L Q-4)$ & $0 / 5$ & $<\mathrm{LQ}$ & $0 / 5$ & $<\mathrm{LQ}$ \\
\hline Sulfadiazine & 1.0 & $9 / 9$ & $\begin{array}{c}10 \pm 6 \\
(1-21)\end{array}$ & $7 / 9$ & $\begin{array}{c}4 \pm 3 \\
(<L Q-8)\end{array}$ & $5 / 5$ & $\begin{array}{c}4 \pm 1 \\
(2-5)\end{array}$ & $4 / 5$ & $\begin{array}{c}1 \pm 1 \\
(<L Q-2)\end{array}$ \\
\hline Sulfameter & 1.0 & $1 / 9$ & $(<L Q-4)$ & $0 / 9$ & $<\mathrm{LQ}$ & $0 / 5$ & $<\mathrm{LQ}$ & $0 / 5$ & $<\mathrm{LQ}$ \\
\hline Sulfathiazole & 1.0 & $3 / 9$ & 1 & $0 / 9$ & $<\mathrm{LQ}$ & $0 / 5$ & $<\mathrm{LQ}$ & $0 / 5$ & $<\mathrm{LQ}$ \\
\hline
\end{tabular}




\begin{tabular}{|c|c|c|c|c|c|c|c|c|c|}
\hline & & & $(1-2)$ & & & & & & \\
\hline Atenolol & 0.02 & $9 / 9$ & $\begin{array}{c}185 \pm 51 \\
(124-251)\end{array}$ & $9 / 9$ & $\begin{array}{l}28 \pm 24 \\
(2-67)\end{array}$ & $5 / 5$ & $\begin{array}{c}588 \pm 156 \\
(454-858)\end{array}$ & $5 / 5$ & $\begin{array}{c}176 \pm 42 \\
(126-236)\end{array}$ \\
\hline Propranolol & 0.02 & $9 / 9$ & $\begin{array}{c}97 \pm 27 \\
(66-131)\end{array}$ & $9 / 9$ & $\begin{array}{c}5 \pm 5 \\
(1-15)\end{array}$ & $5 / 5$ & $\begin{array}{c}197 \pm 46 \\
(162-276)\end{array}$ & $5 / 5$ & $\begin{array}{c}14 \pm 5 \\
(10-23)\end{array}$ \\
\hline Carbamazepine & 1.0 & $9 / 9$ & $\begin{array}{c}215 \pm 85 \\
(19-321)\end{array}$ & $8 / 9$ & $\begin{array}{c}41 \pm 43 \\
(<L Q-113)\end{array}$ & $5 / 5$ & $\begin{array}{c}30 \pm 2 \\
(27-32)\end{array}$ & $4 / 5$ & $\begin{array}{c}8 \pm 2 \\
(<L Q-11)\end{array}$ \\
\hline Oxazepam & 1.2 & $8 / 8$ & $\begin{array}{l}139 \pm 128 \\
(20-354)\end{array}$ & $8 / 8$ & $\begin{array}{l}29 \pm 24 \\
(5-65)\end{array}$ & $5 / 5$ & $\begin{array}{c}409 \pm 132 \\
(251-615)\end{array}$ & $5 / 5$ & $\begin{array}{c}176 \pm 31 \\
(145-210)\end{array}$ \\
\hline Lorazepam & 1.9 & $3 / 8$ & $\begin{array}{c}11 \\
(<L Q-27)\end{array}$ & $1 / 8$ & $(<L Q-6)$ & $4 / 5$ & $\begin{array}{c}34 \pm 2 \\
(<L Q-36)\end{array}$ & $5 / 5$ & $\begin{array}{c}18 \pm 3 \\
(15-23)\end{array}$ \\
\hline Bezafibrate & 0.7 & $8 / 8$ & $\begin{array}{c}36 \pm 42 \\
(1-102)\end{array}$ & $6 / 8$ & $\begin{array}{c}8 \pm 9 \\
(<L Q-26)\end{array}$ & $5 / 5$ & $\begin{array}{c}369 \pm 330 \\
(151-940)\end{array}$ & $5 / 5$ & $\begin{array}{l}187 \pm 149 \\
(84-447)\end{array}$ \\
\hline Fenofibrate & 2.4 & $1 / 8$ & $(<L Q-4)$ & $0 / 8$ & $<\mathrm{LQ}$ & $0 / 8$ & $<\mathrm{LQ}$ & $0 / 8$ & $<\mathrm{LQ}$ \\
\hline Estrone & 1.0 & $4 / 8$ & $\begin{array}{c}7 \pm 2 \\
(<L Q-10)\end{array}$ & $5 / 8$ & $\begin{array}{c}9 \pm 10 \\
(<L Q-26)\end{array}$ & $5 / 5$ & $\begin{array}{c}12 \pm 3 \\
(9-15)\end{array}$ & $5 / 5$ & $\begin{array}{c}5 \pm 1 \\
(4-7)\end{array}$ \\
\hline Testosterone & 1.0 & $1 / 8$ & $(<L Q-1)$ & $0 / 8$ & $<\mathrm{LQ}$ & $2 / 5$ & $(<L Q-1)$ & $0 / 5$ & $<\mathrm{LQ}$ \\
\hline$\Sigma \mathrm{PhPHs}$ & - & - & $\begin{array}{c}2729 \pm 1057 \\
(1358-5158)\end{array}$ & - & $\begin{array}{c}752 \pm 517 \\
(75-1593)\end{array}$ & - & $\begin{array}{c}9892 \pm 2569 \\
(6844-13910)\end{array}$ & - & $\begin{array}{c}2625 \pm 1007 \\
(1711-4226)\end{array}$ \\
\hline
\end{tabular}

Other emerging micropollutants

\begin{tabular}{|c|c|}
\hline Atrazine & 0.2 \\
\hline Diuron & 0.2 \\
\hline Isoproturon & 0.2 \\
\hline PFOA & 1.0 \\
\hline PFOS & 1.0 \\
\hline Bisphenol A & 10 \\
\hline NP & 100 \\
\hline $\mathrm{t}-\mathrm{OP}$ & 0.6 \\
\hline DEHP & 100 \\
\hline DEP & 100 \\
\hline DnBP & 100 \\
\hline Acesulfame & 50 \\
\hline Cyclamate & 50 \\
\hline Saccharin & 50 \\
\hline Sucralose & 250 \\
\hline Triclosan & 10 \\
\hline Methyl paraben & 2.8 \\
\hline Ethyl paraben & 3.5 \\
\hline Propyl paraben & 3.3 \\
\hline Benzyl paraben & 3.0 \\
\hline Butyl paraben & 2.8 \\
\hline Fluorene & 0.2 \\
\hline Phenanthrene & 0.2 \\
\hline
\end{tabular}

\begin{tabular}{|c|c|c|c|}
\hline $5 / 5$ & $\begin{array}{c}4 \pm 1 \\
(3-5)\end{array}$ & $5 / 5$ & $\begin{array}{c}2 \pm 1 \\
(1-2)\end{array}$ \\
\hline $5 / 5$ & $\begin{array}{c}25 \pm 5 \\
(19-30)\end{array}$ & $5 / 5$ & $\begin{array}{c}4 \pm 1 \\
(2-5)\end{array}$ \\
\hline $5 / 5$ & $\begin{array}{c}34 \pm 22 \\
(11-62) \\
\end{array}$ & $5 / 5$ & $\begin{array}{c}12 \pm 6 \\
(5-20) \\
\end{array}$ \\
\hline $5 / 5$ & $\begin{array}{c}25 \pm 9 \\
(14-36)\end{array}$ & $5 / 5$ & $\begin{array}{c}37 \pm 19 \\
(16-57) \\
\end{array}$ \\
\hline $5 / 5$ & $\begin{array}{c}44 \pm 12 \\
(24-56)\end{array}$ & $5 / 5$ & $\begin{array}{c}31 \pm 13 \\
(14-47)\end{array}$ \\
\hline $5 / 5$ & $\begin{array}{c}259 \pm 148 \\
(142-513) \\
\end{array}$ & $5 / 5$ & $\begin{array}{c}78 \pm 24 \\
(52-112) \\
\end{array}$ \\
\hline $5 / 5$ & $\begin{array}{c}841 \pm 681 \\
(143-1895)\end{array}$ & $3 / 5$ & $\begin{array}{c}286 \\
(<L Q-390)\end{array}$ \\
\hline $5 / 5$ & $\begin{array}{c}17 \pm 5 \\
(10-22)\end{array}$ & $5 / 5$ & $\begin{array}{l}16 \pm 15 \\
(4-39)\end{array}$ \\
\hline $4 / 4$ & $\begin{array}{c}1413 \pm 862 \\
(919-2704)\end{array}$ & $4 / 4$ & $\begin{array}{c}861 \pm 489 \\
(377-1300) \\
\end{array}$ \\
\hline $5 / 5$ & $\begin{array}{c}991 \pm 443 \\
(441-1644)\end{array}$ & $5 / 5$ & $\begin{array}{c}437 \pm 149 \\
(298-646)\end{array}$ \\
\hline $5 / 5$ & $\begin{array}{c}932 \pm 631 \\
(355-1986) \\
\end{array}$ & $5 / 5$ & $\begin{array}{c}607 \pm 383 \\
(309-1280) \\
\end{array}$ \\
\hline $4 / 4$ & $\begin{array}{c}8725 \pm 602 \\
(7900-9300) \\
\end{array}$ & $4 / 4$ & $\begin{array}{c}7525 \pm 665 \\
(6700-8200)\end{array}$ \\
\hline $2 / 4$ & $\begin{array}{c}240 \\
(<L Q-430)\end{array}$ & $0 / 4$ & $<\mathrm{LQ}$ \\
\hline $4 / 4$ & $\begin{array}{c}1355 \pm 572 \\
(840-2100)\end{array}$ & $4 / 4$ & $\begin{array}{c}703 \pm 284 \\
(450-1100)\end{array}$ \\
\hline $4 / 4$ & $\begin{array}{c}7150 \pm 545 \\
(6500-7800) \\
\end{array}$ & $4 / 4$ & $\begin{array}{c}5875 \pm 222 \\
(5600-6100) \\
\end{array}$ \\
\hline $3 / 3$ & $\begin{array}{c}135 \\
(121-158) \\
\end{array}$ & $3 / 3$ & $\begin{array}{c}103 \\
(86-119) \\
\end{array}$ \\
\hline $3 / 3$ & $\begin{array}{c}65 \\
(31-102) \\
\end{array}$ & $3 / 3$ & $\begin{array}{c}11 \\
(10-13)\end{array}$ \\
\hline $3 / 3$ & $\begin{array}{c}40 \\
(27-57) \\
\end{array}$ & $2 / 3$ & $\begin{array}{c}5 \\
(<L Q-7)\end{array}$ \\
\hline $3 / 3$ & $\begin{array}{c}56 \\
(37-81)\end{array}$ & $2 / 3$ & $\begin{array}{c}5 \\
(<L Q-5)\end{array}$ \\
\hline $1 / 3$ & $(<L Q-4)$ & $1 / 3$ & $(<L Q-3)$ \\
\hline $2 / 3$ & $\begin{array}{c}10 \\
(<L Q-13)\end{array}$ & $0 / 3$ & $<\mathrm{LQ}$ \\
\hline $3 / 3$ & $\begin{array}{c}1.7 \\
(0.3-4.2)\end{array}$ & $3 / 3$ & $\begin{array}{c}3.0 \\
(2.6-3.4)\end{array}$ \\
\hline $3 / 3$ & 16.7 & $3 / 3$ & 24.2 \\
\hline
\end{tabular}




\begin{tabular}{|c|c|}
\hline Anthracene & 0.2 \\
\hline Fluoranthene & 0.2 \\
\hline Pyrene & 0.2 \\
\hline Benzo[a]anthracene & 0.2 \\
\hline Chrysene & 0.2 \\
\hline Benzo[b]fluoranthene & 0.2 \\
\hline Benzo[k]fluoranthene & 0.2 \\
\hline Benzo[a]pyrene & 0.2 \\
\hline Indeno[123]pyrene & 0.2 \\
\hline Dibenzo[ah]anthracene & 0.2 \\
\hline Benzo[ghi]perylene & 0.2 \\
\hline
\end{tabular}

\begin{tabular}{|c|c|c|c|}
\hline & $(13.0-19.1)$ & & $(10.2-33.3)$ \\
\hline $3 / 3$ & $\begin{array}{c}0.6 \\
(0.5-0.8)\end{array}$ & $3 / 3$ & $\begin{array}{c}16.7 \\
(13.0-19.1)\end{array}$ \\
\hline $3 / 3$ & $\begin{array}{c}3.2 \\
(2.6-3.9)\end{array}$ & $3 / 3$ & $\begin{array}{c}2.6 \\
(2.4-2.8)\end{array}$ \\
\hline $3 / 3$ & $\begin{array}{c}2.4 \\
(2.1-2.8)\end{array}$ & $3 / 3$ & $\begin{array}{c}1.6 \\
(1.4-1.8)\end{array}$ \\
\hline $0 / 3$ & $<\mathrm{LQ}$ & $1 / 3$ & $(<L Q-0.9)$ \\
\hline $3 / 3$ & $\begin{array}{c}1.5 \\
(1.2-1.6)\end{array}$ & $3 / 3$ & $\begin{array}{c}1.5 \\
(0.7-1.9)\end{array}$ \\
\hline $3 / 3$ & $\begin{array}{c}3.3 \\
(2.2-4.0)\end{array}$ & $3 / 3$ & $\begin{array}{c}3.2 \\
(1.5-4.2)\end{array}$ \\
\hline $3 / 3$ & $\begin{array}{c}1.2 \\
(0.9-1.4)\end{array}$ & $3 / 3$ & $\begin{array}{c}1.5 \\
(0.5-2.5)\end{array}$ \\
\hline $3 / 3$ & $\begin{array}{c}1.4 \\
(0.9-1.7)\end{array}$ & $3 / 3$ & $\begin{array}{c}1.8 \\
(0.7-3.0)\end{array}$ \\
\hline $3 / 3$ & $\begin{array}{c}2.0 \\
(1.0-2.6)\end{array}$ & $3 / 3$ & $\begin{array}{c}2.0 \\
(0.8-3.3)\end{array}$ \\
\hline $3 / 3$ & $\begin{array}{c}0.5 \\
(0.3-0.6)\end{array}$ & $3 / 3$ & $\begin{array}{c}1.8 \\
(0.3-4.3)\end{array}$ \\
\hline $3 / 3$ & $\begin{array}{c}2.0 \\
(1.1-2.6)\end{array}$ & $3 / 3$ & $\begin{array}{c}1.7 \\
(0.7-2.3)\end{array}$ \\
\hline
\end{tabular}

$\mathrm{LQ}=$ limit of quantification

$\mathrm{N}$ = number of quantification / campaigns performed.

Av. $\pm \mathrm{SD}=$ average \pm standard deviation (calculated only when $\mathrm{N}>3$ ). 


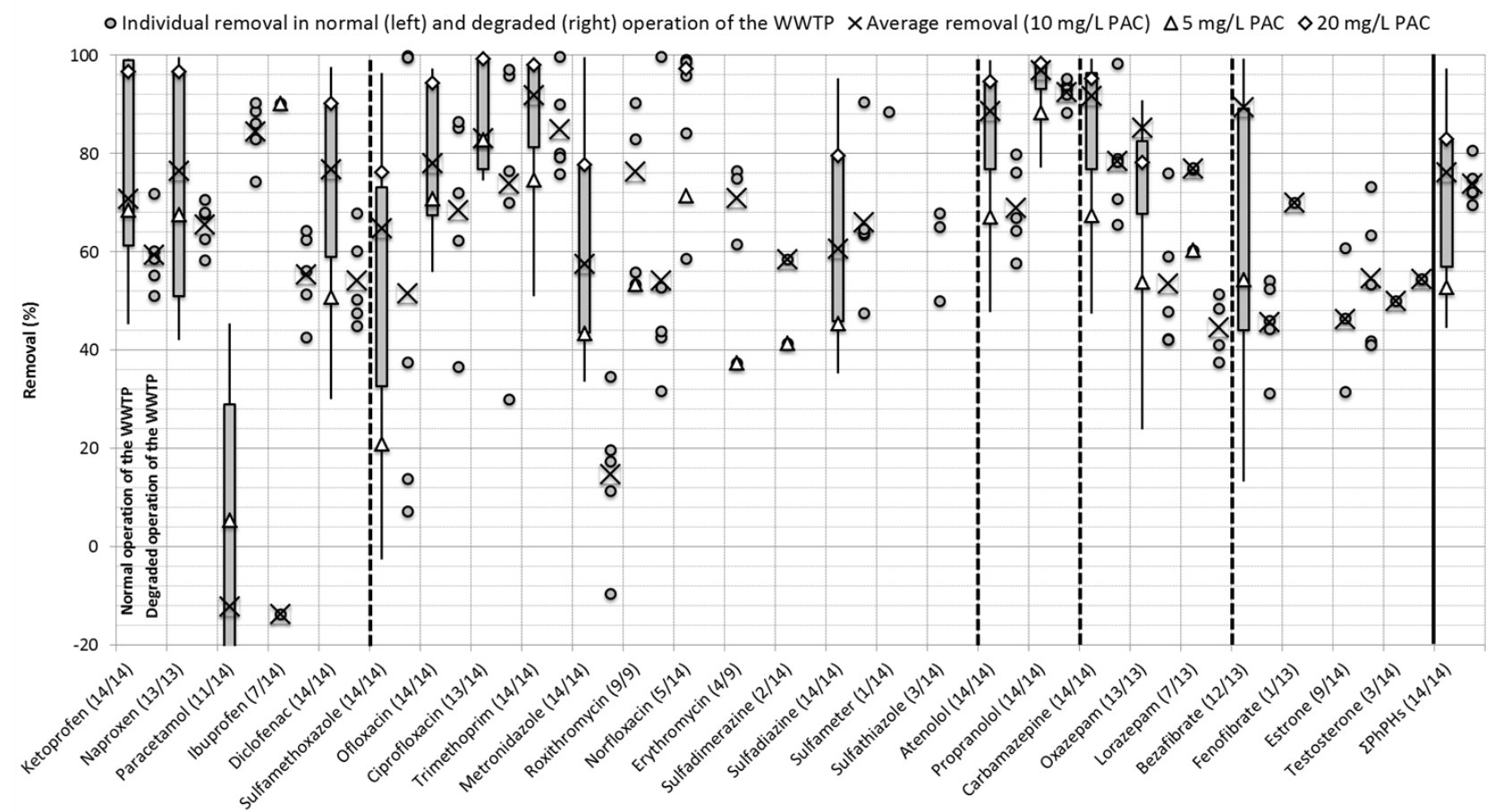

Figure 2 - Removals of pharmaceuticals and hormones ( $\mathrm{N}=26)$ by PAC treatment during nominal (left) and degraded (right) WWTP configurations (min - Q1 - Q2 - Q3 - max or individual values) - occurrence in brackets 


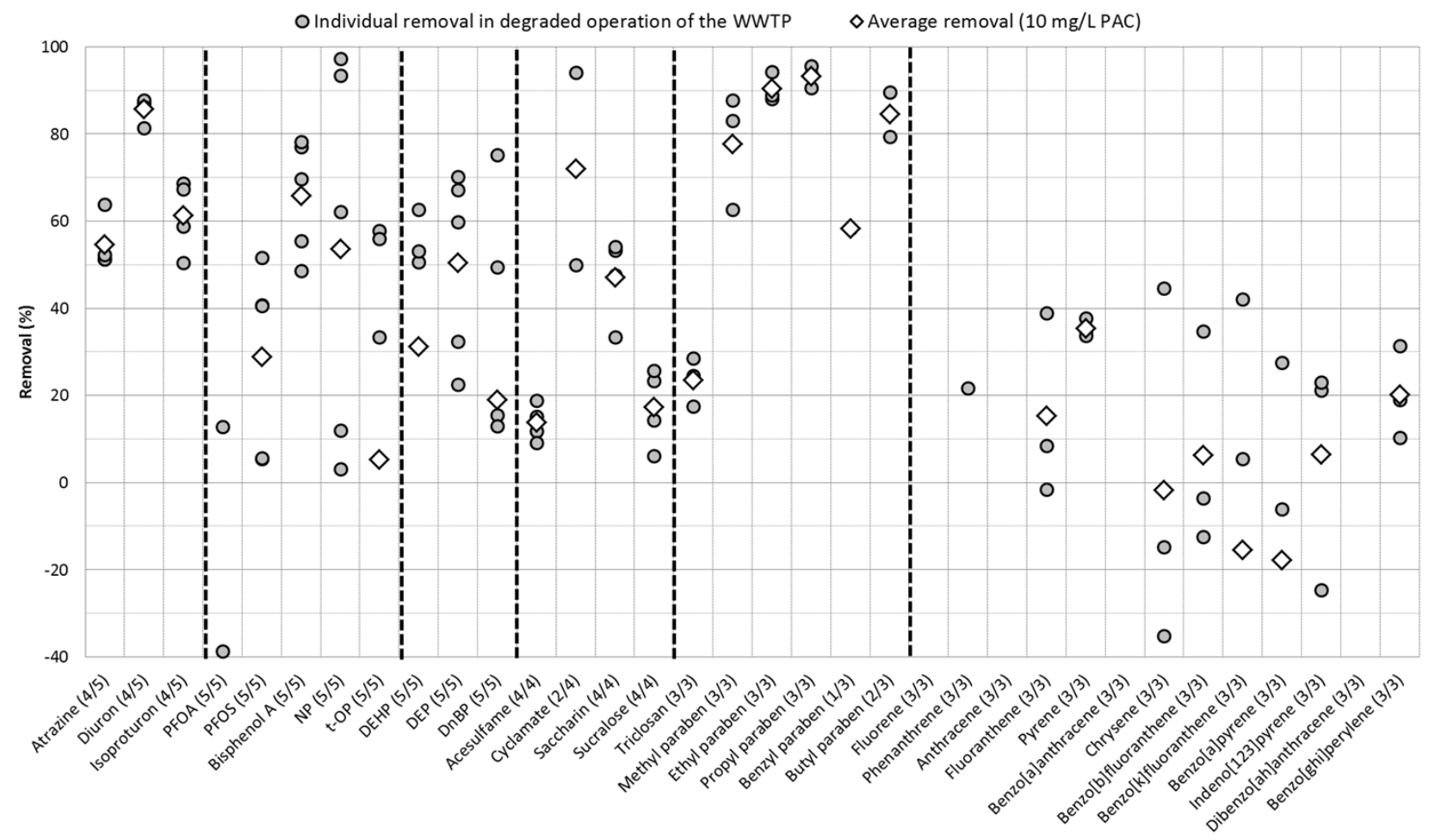

Figure 3 - Removals of the other emerging micropollutants by PAC, in degraded configuration of the WWTP. 

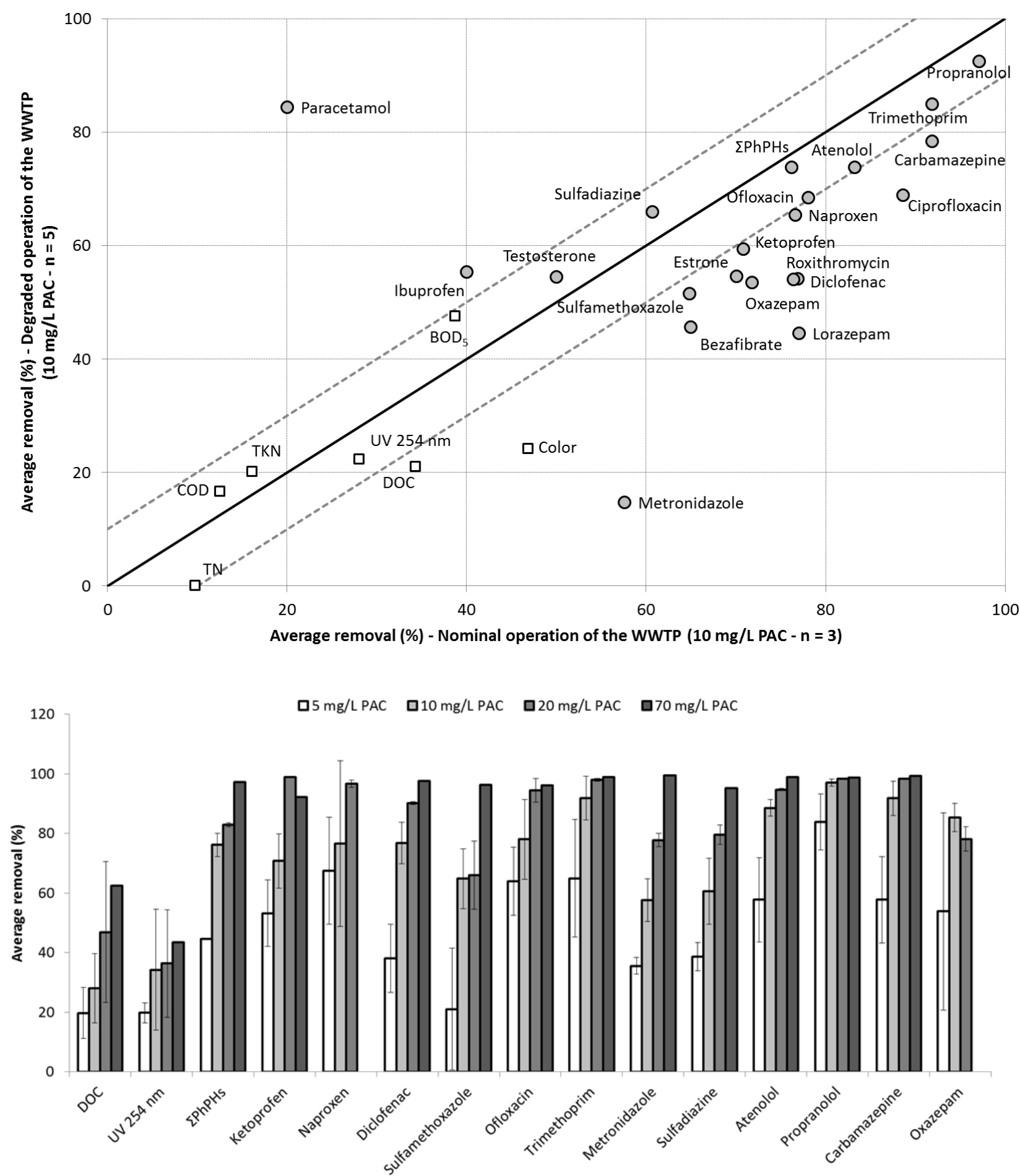
wastewater - influence of the water quality (top) and the fresh PAC dose (bottom) 